\title{
A comprehensive method for amplicon- based and metagenomic characterization of viruses, bacteria, and eukaryotes in freshwater samples
}

Miguel I. Uyaguari-Diaz ${ }^{1,9}$, Michael Chan', Bonnie L. Chaban², Matthew A. Croxen', Jan F. Finke 3,4, Janet E. Hill', Michael A. Peabody ${ }^{7}$, Thea Van Rossum7, Curtis A. Suttle ${ }^{3,4,5,8}$, Fiona S. L. Brinkman ${ }^{7}$, Judith Isaac-Renton ${ }^{1,9}$, Natalie A. Prystajecky ${ }^{1,9}$ and Patrick Tang ${ }^{10^{*}}$

\begin{abstract}
Background: Studies of environmental microbiota typically target only specific groups of microorganisms, with most focusing on bacteria through taxonomic classification of $16 \mathrm{~S}$ rRNA gene sequences. For a more holistic understanding of a microbiome, a strategy to characterize the viral, bacterial, and eukaryotic components is necessary.

Results: We developed a method for metagenomic and amplicon-based analysis of freshwater samples involving the concentration and size-based separation of eukaryotic, bacterial, and viral fractions. Next-generation sequencing and culture-independent approaches were used to describe and quantify microbial communities in watersheds with different land use in British Columbia. Deep amplicon sequencing was used to investigate the distribution of certain viruses ( 923 and RdRp), bacteria (16S rRNA and cpn60), and eukaryotes (18S rRNA and ITS). Metagenomic sequencing was used to further characterize the gene content of the bacterial and viral fractions at both taxonomic and functional levels.
\end{abstract}

Conclusion: This study provides a systematic approach to separate and characterize eukaryotic-, bacterial-, and viral-sized particles. Methodologies described in this research have been applied in temporal and spatial studies to study the impact of land use on watershed microbiomes in British Columbia.

Keywords: Microbiome, Watersheds, Amplicon sequencing, Metagenomes, Metagenomics, Microbial fractions

\section{Background}

Water is the most basic and important natural resource on our planet. While water is a renewable resource, an expanding population and increased land use create stress on the aquatic environment and threats to water quality [1-3]. Although there are many users of water, including animals, agriculture, and industry, the current emphasis for water quality assessment is testing at the tap for the purpose of human consumption rather than at the source watershed.

\footnotetext{
* Correspondence: ptang@sidra.org

${ }^{10}$ Department of Pathology, Sidra Medical and Research Center, PO Box 26999, Doha, Qatar

Full list of author information is available at the end of the article
}

Laboratory tests for fecal pollution use traditional culture-based methods to detect bacteria such as Escherichia coli and total coliforms. Not only are these methods slow and inaccurate due to differences in enumeration strategies [4], but also they measure only a fraction of the microorganisms in the sample $[5,6]$, missing important perturbations in the microbiota.

Environmental or human disturbances can lead to perturbations in the watershed microbiome including changes in the endogenous microorganisms or the introduction of human or animal fecal microbiota. These changes in community structure in combination with environmental parameters may pinpoint to the source of disturbance in water quality. Thus, a 
better understanding of the entire watershed microbiome and sources of pollution in watersheds will be critical for assessing microbial community changes and associated threats to both ecosystem and human health. Previous work has demonstrated that (i) niche environments such as watersheds have unique microbial taxa signatures and (ii) microbial markers can be used to detect microbial pollution in water $[7,8]$. Still, the microbiomes of freshwater ecosystems have not been as comprehensively studied as have other aquatic environments such as marine ecosystems [9-11].

Next-generation sequencing and culture-independent approaches enable the detection of these perturbations and the identification of biomarkers for pollution detection and source attribution. There are multiple studies that have been conducted using culture-independent approaches such as deep amplicon sequencing of the $16 \mathrm{~S}$ rRNA gene and shotgun metagenomics to characterize bacterial communities and assess water quality and the overall ecology in freshwater ecosystems [8, 12-15]. While these studies have identified microbial signatures of water quality, they are based upon the analysis of a specific gene or microbial fraction (mainly bacteria) leaving other microbial fractions largely unexplored. For instance, plant viruses can be good markers for human fecal contamination $[16,17]$ and bacteriophages can be used for microbial source tracking [18], demonstrating that surveys of watershed microbiomes need to expand beyond the typical bacterial 16S rRNA or single fraction studies.

To date, there is only one study that has characterized the different major microbial domains within the same environmental sample (soil) [19]. The present study describes a series of methods developed to more comprehensively characterize freshwater microbial communities (eukaryotes, bacteria, and viruses) as a single unit. Water samples from three non-interconnected watersheds in southwestern British Columbia affected by different land use (agricultural, urban, and protected sites) were concentrated and fractionated by size using filtration then characterized using amplicon sequencing and metagenomics (sequencing all the genetic material in a sample). Sequence-based metagenomics aimed for bacterial and viral communities, while deep amplicon sequencing included 18S rRNA gene, internal transcribed spacer (ITS) for eukaryotes, and 16S rRNA and chaperonin-60 (cpn60) genes for bacteria. Due to the lack of a universal gene in viruses, amplicon sequencing was used to study only selected DNA and RNA viruses. Gene 23 ( $g 23$ ), which encodes the major capsid protein of T4-like bacteriophages, has been widely used for phylogenetic studies in different environments including aquatic environments [10, 20-23]. All known RNA viruses employ an RNA- dependent RNA polymerase ( $R d R p)$ for replication [24]. As the largest group of RNA viruses, Picornavirales have been reported to infect a wide diversity of eukaryotes in aquatic environments [11, 25-28]; the $R d R p$ gene from this order was selected to complement viral RNA metagenomes in watersheds.

Additionally, traditional bacterial markers of low water quality such as total coliforms and $E$. coli were also included as part of this study. These series of approaches were piloted in order to validate the laboratory methods and define the baseline microbiota in three differently affected watersheds of southwestern British Columbia. Ultimately, these methods will be applied in larger longitudinal studies to study the impact of land use on watershed microbiomes and identify novel biomarkers of water quality.

\section{Methods}

\section{Sample collection}

Forty-liter samples were collected in sterile plastic carboys from three different watersheds in southwestern British Columbia, each representing a different land use type (protected, agricultural, and urban). Sampling within each site was conducted in two to three locations (upstream, downstream, and at the "polluted" site). Table 1 summarizes the description of sampling sites. Land use was the primary determinant of watershed selection. Watersheds were selected in collaboration with provincial agencies and scientists who have conducted research in these locations. A total of seven samples were collected within a 1.5-month period (March-April 2012). Samples were pre-filtered in situ using a $105-\mu \mathrm{m}$ spectra/mesh polypropylene filter (SpectrumLabs, Rancho Dominguez, CA) and kept at $4{ }^{\circ} \mathrm{C}$ for transport to the laboratory for processing and storage within $2 \mathrm{~h}$ of the last sample collection. Ten liters of ultrapure (type 1) water (Milli-Q, Millipore Corporation, Billerica, MA) was used as a filtration control.

\section{Metadata}

Physico-chemical water quality parameters were measured in situ using a YSI Professional Plus handheld multiparameter instrument (YSI Inc., Yellow Springs, $\mathrm{OH})$, a VWR turbidity meter model No. 66120-200 (VWR, Radnor, PA) and a Swoffer 3000 current meter (Swoffer Instrumentsz, Seattle, WA). Total coliform and E. coli counts were determined using Colilert-24 (IDEXX Laboratories, Westbrook, ME). Chemical analysis included dissolved chloride (mg/L) and ammonia (mg/L) using automated colorimetric (SM-4500-Cl G) and phenate methods (SM-4500-NH3 G) [29]. Additionally, nutrients (orthophosphates, nitrites, and nitrates) were analyzed following methods described by Murphy and Riley [30] and Wood et al. [31], respectively. 
Table 1 Description of sampling sites

\begin{tabular}{|c|c|c|c|c|c|c|}
\hline Watershed & $\begin{array}{l}\text { Site } \\
\text { name }\end{array}$ & $\begin{array}{l}\text { Average depth } \\
\text { (m) at cross } \\
\text { section }\end{array}$ & $\begin{array}{l}\text { Average width } \\
(\mathrm{m}) \text { at cross } \\
\text { section }\end{array}$ & $\begin{array}{l}\text { Elevation from } \\
\text { the sea level }(\mathrm{m})\end{array}$ & $\begin{array}{l}\text { Water } \\
\text { flow }\left(\mathrm{m}^{3} / \mathrm{s}\right)\end{array}$ & Description \\
\hline \multirow[t]{2}{*}{ Urban $^{a, b}$} & UPL & 0.17 & 1.26 & 119 & 0.06 & At site of urban "pollution," in residential area. \\
\hline & UDS & 0.14 & 2.68 & 8 & 0.29 & Downstream of urban "pollution," 1 km from UPL. \\
\hline \multirow[t]{3}{*}{ Agricultural $^{\mathrm{C}}$} & AUP & 0.16 & 1.71 & 118 & 0.16 & $\begin{array}{l}\text { Upstream of agricultural "pollution." Not affected by } \\
\text { agricultural activity, with minimal housing nearby. }\end{array}$ \\
\hline & APL & 0.79 & 7.33 & 10 & 2.11 & $\begin{array}{l}\text { At site of agricultural "pollution." AUP is upstream of } \\
\text { APL, separated by } 9 \mathrm{~km} \text {. Multiple farms near this site }\end{array}$ \\
\hline & ADS & 1.72 & 25.5 & 8 & 9.97 & $\begin{array}{l}\text { Downstream of agricultural "pollution." ADS is } \\
\text { downstream of APL, } 2.5 \mathrm{~km} \text { away. }\end{array}$ \\
\hline \multirow[t]{2}{*}{ Protected } & PUP & 0.24 & 7.7 & 198 & 0.60 & $\begin{array}{l}\text { Upstream of drinking water reservoir in protected } \\
\text { watershed. }\end{array}$ \\
\hline & PDS & 2.1 & 2.1 & 111 & 1.01 & $\begin{array}{l}\text { Downstream of PUP-fed reservoir, collected after } \\
\text { passing through an } 8.8 \mathrm{~km} \text { pipe. }\end{array}$ \\
\hline
\end{tabular}

${ }^{a}$ Average distance between urban and agricultural watershed: $63 \mathrm{~km}$

${ }^{b}$ Average distance between urban and protected watershed: $101 \mathrm{~km}$

${ }^{c}$ Average distance between agricultural and protected watershed: $132 \mathrm{~km}$

\section{Fraction separation}

Microbial fractions were separated through a combination of serial filtration approaches. Following pre-filtration in situ, water was filtered through a $1-\mu \mathrm{m}$ Envirochek HV (Pall Corporation, Ann Harbor, MI) sampling capsule to capture eukaryotic-sized particles, followed by filtration through a $0.2-\mu \mathrm{m}$ 142-mm Supor-200 membrane disc filters (Pall Corporation, Ann Harbor, MI) to capture the bacterial-sized particles. To remove any remaining bacterial cells, the permeate was filtered again using a $0.2-\mu \mathrm{m}$ Supor Acropak 200 sterile cartridge (Pall Corporation, Ann Harbor, MI) prior to tangential flow filtration (TFF). Viral-sized particles were concentrated to approximately $450 \mathrm{~mL}$ as described by Suttle et al. [32] and Culley et al. [26], using a regenerated cellulose Prep/Scale TFF cartridge (Millipore Corporation, Billerica, MA) with a 30-kDa molecular-weight cutoff and nominal filter area of $0.23 \mathrm{~m}^{2}$.

\section{Collection, fixation, and particle quantitation of environmental samples using flow cytometry (FCM)}

Nine hundred and eighty-microliter aliquots of raw water and $0.2 \mu \mathrm{m}$ permeate, ultrafiltrate, and viral concentrate were collected in duplicates during the filtration process. Samples were fixed with $20 \mu \mathrm{l}$ of $25 \%$ glutaraldehyde to reach a final concentration of $0.5 \%$ glutaraldehyde, inverted to mix, incubated at $4{ }^{\circ} \mathrm{C}$ in the dark for $20 \mathrm{~min}$, and then transferred to $-80{ }^{\circ} \mathrm{C}$ freezer for storage and further analysis. Abundance of viral and bacterial-sized particles were determined in duplicate water samples using a FACSCalibur flow cytometer (Beckton Dickinson, San Jose, CA) with a 15-mW 488$\mathrm{nm}$ air-cooled argon-ion laser as described by Brussaard (2004) [33]. Analysis of the FCM results was conducted using CYTOWIN version 4.31 (2004) [34].

\section{Elution and concentration of microbial cells and viral particles}

Mechanical procedures involving shaking and centrifugation were used to remove and concentrate microbial cells from the filters. Cells were washed with $\times 1$ phosphate-buffered solution (PBS) and $0.01 \%$ Tween $\mathrm{pH}$ 7.4. Eukaryotic cells retained in the 1- $\mu \mathrm{m}$ Envirochek HV capsules were eluted according to the manufacturer's protocol (Pall Corporation, Ann Harbor, MI). Eluates $(\sim 500 \mu \mathrm{L})$ of eukaryotic cells were dispensed into 1.7$\mathrm{mL}$ microcentrifuge tubes and further precipitated by centrifugation $\left(15 \mathrm{~min}, 1500 \times g, 4{ }^{\circ} \mathrm{C}\right)$. Samples were kept at $-80{ }^{\circ} \mathrm{C}$ for further nucleic acid extraction.

To minimize the number of DNA extraction tubes, the $0.2-\mu \mathrm{m}$ Supor membrane disc filter(s) was washed with $15 \mathrm{~mL}$ of PBS to remove bacterial cells followed by centrifugation $\left(15 \mathrm{~min}, 3300 \times g, 4{ }^{\circ} \mathrm{C}\right)$. Aliquots of the washed cell suspension were stored at $-80{ }^{\circ} \mathrm{C}$ for further DNA extraction. Viral-sized particles eluted in $450 \mathrm{~mL}$ of sample required further concentration by ultracentrifugation $\left(4 \mathrm{~h}, 121,000 \times g, 4^{\circ} \mathrm{C}\right)$. Viral-sized concentrate pellets were resuspended in $\times 1$ PBS to reach a final volume of approximately 5 to $6 \mathrm{~mL}$ and incubated overnight at $4{ }^{\circ} \mathrm{C}$ with constant agitation (180 rpm). An evaluation of ultracentrifugation as an approach to further concentrate viral-sized particles is also described here.

\section{Concentration of viral particles by ultracentrifugation}

Validation of ultracentrifugation as a method to isolate virus-like particles was conducted using two DNA and RNA viruses isolated from clinical specimens at the British Columbia Centre for Disease Control (BCCDC): adenovirus (90-100 nm) and enterovirus (Coxsackie B2, $\sim 30 \mathrm{~nm}$ ). Both viruses are routinely used as controls at 
the BCCDC. An aliquot of $0.25 \mu \mathrm{l}$ of adenovirus and enterovirus control stocks was inoculated into A549 and primary Rhesus monkey kidney cell cultures (Diagnostic Hybrids, Athens, OH), respectively. Once the cytophatic effect was $3+$, cells were harvested in minimal essential media (MEM) with $2 \%$ fetal calf serum (Sigma-Aldrich, St. Louis, MO), separately brought up to a final volume of $16 \mathrm{~mL}$, and stored at $-80{ }^{\circ} \mathrm{C}$ until later processing. For further cell lysis and release of viral particles, samples were subjected to three rounds of freeze-thaw. Following the final thaw, samples were filtrated through a $0.2-\mu \mathrm{m}$ Supor membrane syringe filters (Pall Corporation, Ann Harbor, MI) and spiked with $435 \mathrm{~mL}$ of MEM. The recovery efficiency was evaluated for both supernatant and concentrated pellets at different time points $(1,2$, and $4 \mathrm{~h})$ of the ultracentrifugation process $\left(121,000 \times g, 4{ }^{\circ} \mathrm{C}\right)$. Virus concentrate pellets were incubated overnight at $4{ }^{\circ} \mathrm{C}$ on a shaker. At least duplicate aliquots from the different stages of the previously described processes were collected for flow cytometry counts, nucleic acid extraction, and quantitation of viruses in samples.

Nucleic acid extraction of adenoviruses and enteroviruses Samples collected throughout the ultracentrifugation process were pre-treated with $1 \times$ RNAsecure (Life Technologies, Carlsbad, CA) and 5 units (U) of DNase I (Epicentre Biotechnologies, Madison, WI). This reaction was terminated by adding $10 \mathrm{mM}$ EDTA ( $\mathrm{pH} 8.0$ ) for $15 \mathrm{~min}$ at $65{ }^{\circ} \mathrm{C}$. DNA and RNA from adenoviruses and enteroviruses, respectively, from were extracted using the NucliSens easyMAG system (bioMérieux, Craponne, France). Nucleic acids were further precipitated using 0.1 volumes of 3-M sodium acetate and two volumes of $100 \%$ ethanol, washed with $1 \mathrm{~mL}$ of ice-cold $70 \%$ ethanol, and resuspended in $10 \mathrm{mM}$ Tris solution. Nucleic acid concentration and purity was assessed with Qubit dsDNA high sensitivity and RNA assay kits in a Qubit 2.0 fluorometer (Life Technologies, Carlsbad, CA) and NanoDrop spectrophotometer (NanoDrop technologies, Inc., Wilmington, DE), respectively.

\section{Quantitative polymerase chain reaction (qPCR) of adenoviruses and enteroviruses \\ Quantitation of adenoviruses}

Detection of adenoviruses was carried out using a combination of primers described by Wong et al., 2008 [35] (Table S1). These primer sets amplify a conserved region (81-87 bp) of the hAdV hexon gene. DNA extracted from raw samples was used as template to generate amplicons for standard curve. PCR conditions were conducted as follows: $94{ }^{\circ} \mathrm{C}$ for $5 \mathrm{~min}$, followed by 35 cycles of $94{ }^{\circ} \mathrm{C}$ for $30 \mathrm{~s}, 53{ }^{\circ} \mathrm{C}$ for $30 \mathrm{~s}, 72{ }^{\circ} \mathrm{C}$ for $30 \mathrm{~min}$, and a final extension at $72{ }^{\circ} \mathrm{C}$ for $10 \mathrm{~min}$. PCR amplicons were purified with a QIAQuick PCR Purification Kit (Qiagen Sciences, Maryland, MD) according to the manufacturer's instructions.

\section{Quantitation of enteroviruses}

RNA $(4 \mu \mathrm{l})$ extracted from raw samples was first treated with Turbo DNase I (Life Technologies, Carlsbad, CA) following the manufacturer's instructions. RNA was then converted into complementary DNA (cDNA) using Superscript III reverse transcriptase (Life Technologies, Carlsbad, CA). Amplification of the UTRe gene in enteroviruses was conducted using primers described by Verstrepen et al. [36] and Watzinger et al. [37] (Table S1). This primer set amplifies a specific 148-bp region within this gene. cDNA from raw samples was used as template to generate amplicons for standard curve. PCR conditions were conducted as follows: $94{ }^{\circ} \mathrm{C}$ for $5 \mathrm{~min}$, followed by 35 cycles of $94{ }^{\circ} \mathrm{C}$ for $30 \mathrm{~s}, 51{ }^{\circ} \mathrm{C}$ for $30 \mathrm{~s}$, $72{ }^{\circ} \mathrm{C}$ for $30 \mathrm{~min}$, and a final extension at $72{ }^{\circ} \mathrm{C}$ for $10 \mathrm{~min}$. PCR amplicons were purified with a QIAQuick PCR Purification Kit (Qiagen Sciences, Maryland, MD) according to the manufacturer's instructions.

Standard curves for adenoviruses and enteroviruses were generated by ligating purified amplicons of adenoviruses and enteroviruses into pCR2.1-TOPO cloning vectors (Invitrogen) and transformed into One Shot $E$. coli DH5 $\alpha$-T1R competent cells following the manufacturer's protocol. One transformant was selected and grown overnight at $37^{\circ} \mathrm{C}$ in LB broth with $50 \mu \mathrm{g} / \mathrm{mL}$ of kanamycin. Plasmids were extracted and purified using Purelink Quick Plasmid Miniprep kit (Life Technologies, Carlsbad, CA) and quantified using Qubit dsDNA high sensitivity assay kit (Life Technologies, Carlsbad, CA). Plasmid DNA was linearized by digestion with the BamHI-HF endonuclease (New England BioLabs Inc., Ipswich, MA). Serial dilutions of the linearized plasmid were used as templates to generate standard curves for qPCR and RT-qPCR. Each $20-\mu$ l real-time PCR mixture consisted of $10 \mu \mathrm{l}$ of Fast SYBR Green Master Mix (2X) Real-Time PCR Master Mix (Life Technologies, Carlsbad, CA), $250 \mathrm{nM}$ each primer, and $1 \mu \mathrm{l}$ of template DNA or cDNA. The thermal cycling conditions consisted of initial denaturation for $20 \mathrm{~s}$ at $95^{\circ} \mathrm{C}$, followed by 40 cycles of $3 \mathrm{~s}$ at $95{ }^{\circ} \mathrm{C}$ and $20 \mathrm{~s}$ at $60^{\circ} \mathrm{C}$. Gene copy numbers for each sample were run in triplicate using a 7900 HT Fast RealTime PCR system (Life Technologies, Carlsbad, CA). To verify the absence of non-specific amplification, a dissociation step was included and amplicons were analyzed on a $1.5 \%$ agarose gel.

\section{Nucleic acid extraction and quality controls}

Before extraction and to facilitate disruption of eukaryotic cells, eight freeze-thaw cycles, followed by overnight proteinase $\mathrm{K}$ digestion (Qiagen Sciences, 
Germantown, MD), were conducted for this fraction [38]. DNA was extracted from eukaryotes and bacterial cell fractions using the UltraClean Soil DNA Kit (MoBio, Carlsbad, CA) as per the manufacturer's instructions. Concentrated viral-sized particles were pre-treated with 1X RNAsecure (Life Technologies, Carlsbad, CA) and $5 \mathrm{U}$ of DNase I (Epicentre Biotechnologies, Madison, WI). This reaction was terminated with $10 \mathrm{mM}$ EDTA (pH 8.0) for $15 \mathrm{~min}$ at $65^{\circ} \mathrm{C}$. Total nucleic acids were extracted from the viral fraction using the NucliSens easyMAG system (bioMérieux, Craponne, France). Nucleic acids from all fractions were further precipitated using 0.1 volumes of $3-\mathrm{M}$ sodium acetate, two volumes of $100 \%$ ethanol, and $5 \mu \mathrm{l}$ of $5 \mu \mathrm{g} / \mu \mathrm{l}$ linear acrylamide. Samples were stored at $-80{ }^{\circ} \mathrm{C}$ overnight then centrifuged at $17,000 \times g$ for $30 \mathrm{~min}$ at $4{ }^{\circ} \mathrm{C}$. Supernatants were discarded, and pellets were washed with $70 \%$ ice-cold ethanol, air dried, and resuspended in $10 \mathrm{mM}$ Tris $\mathrm{Cl}$, $\mathrm{pH}$ 8.5. Concentration, purity, and average size of nucleic acids were assessed with Qubit dsDNA High Sensitivity or RNA Assay kits in a Qubit 2.0 fluorometer (Life Technologies, Carlsbad, CA), NanoDrop spectrophotometer (NanoDrop Technologies, Inc., Wilmington, DE), and Agilent High Sensitivity DNA kit (Agilent Technologies, Inc., Santa Clara, CA), respectively.

Cysts and oocysts from Giardia lamblia and Cryptosporidium parvum (Waterborne, Inc., New Orleans, LA), respectively, were used as positive control for DNA extraction and amplification of the 18S rRNA gene. An isolate of Aspergillus flavus was used as a control for amplification of the ITS region. A strain of E. coli (ATCC 25922) was used as positive control for $16 \mathrm{~S}$ rRNA and cpn60 genes. For DNA viruses and $g 23$ gene, a myovirus propagated in Synechococcus sp. strain WH7803 was used as a positive control. As a positive control for RNA viruses and RdRp amplicons, cultures of Heterosigma akashiwo were grown and infected with HaRNAV (isolate SOG263). Negative controls included sterile water and PBS.

\section{cDNA synthesis and random amplification of the viral fraction}

A modified adapter nonamer approach described by Wang et al. [39] was used for cDNA synthesis and increase yields of the viral fraction. An aliquot of $4 \mu \mathrm{l}$ from the total nucleic acids in the viral fraction was treated with Turbo DNase I (Life Technologies, Carlsbad, CA), following the manufacturer's instructions. DNAsed samples (RNA) were then converted to cDNA using random nonamer primer A (5'-GTTTCCCACTGGAGGATAN9-3') and Superscript III reverse transcriptase (Life Technologies, Carlsbad, CA). Second strand synthesis was carried out using two rounds of Sequenase Version 2.0 DNA Polymerase (Affymetrix, Santa Clara, CA).
Samples were stored at $-20{ }^{\circ} \mathrm{C}$ until further processing. Subsequently, $5 \mu \mathrm{l}$ of double-stranded cDNA samples was used as templates in a 50- $\mu \mathrm{l}$ PCR reaction consisting of $5 \mathrm{U}$ of KlenTaq LA polymerase, 1X Klentaq PCR buffer, 0.2-mM nucleotides, $2 \mu \mathrm{M}$ of primer B (5'GTTTCCCACTGGAGGATA-3'). Random amplification was carried out as follows: $94{ }^{\circ} \mathrm{C}$ for $4 \mathrm{~min}, 68{ }^{\circ} \mathrm{C}$ for 5 min followed by 30 cycles of $94{ }^{\circ} \mathrm{C}$ for $30 \mathrm{~s}, 50{ }^{\circ} \mathrm{C}$ for $1 \mathrm{~min}$, and $68{ }^{\circ} \mathrm{C}$ for $1 \mathrm{~min}$ and a final extension at $68^{\circ} \mathrm{C}$ for $2 \mathrm{~min}$. The amplified material was then cleaned up with Agencourt AMPure XP-PCR purification system (Beckman Coulter Inc., Brea, CA) at a $1.8 \times$ ratio. Primer B was excised using $4 \mathrm{U}$ of BpmI (New England BioLabs Inc., Ipswich, MA). Digested products were cleaned up with Agencourt AMPure XP-PCR purification system (Beckman Coulter Inc., Brea, CA) at a $1.8 \times$ ratio. Finally, samples were end-repaired using $0.2-\mathrm{mM}$ nucleotides, $1 \times$ T4 ligase buffer, $3 \mathrm{U}$ of T4 DNA polymerase, $5 \mathrm{U}$ of DNA polymerase I large (Klenow) fragment, and $10 \mathrm{U}$ of T4 polynucleotide kinase (New England BioLabs Inc., Ipswich, MA). For random amplification of viral DNA, the random nonamer primer A and Sequenase DNA Polymerase were used as described above. Fragments generated in the random amplification process were further analyzed using the Agilent High Sensitivity DNA Kit (Agilent Technologies, Inc., Santa Clara, CA) and quantified using the Qubit dsDNA High Sensitivity Assay Kit (Life Technologies, Carlsbad, CA).

\section{Amplification of gene targets}

Table 2 summarizes the primer sets and conditions used for the generation of amplicons described in the present study. Nucleic acids extracted from water samples and controls were analyzed for $\mathrm{V} 1-\mathrm{V} 3$ regions of the $18 \mathrm{~S}$ rRNA gene and internal transcribed spacer (ITS1/ ITS2) region for eukaryotes; hypervariable V3-V4 regions of the $16 \mathrm{~S}$ rRNA and cpn60 genes for bacteria; and $g 23$ for T4-like bacteriophages and the RdRp gene for picorna-like viruses. Each PCR reaction consisted of $1.5-\mathrm{mM} \mathrm{MgCl}_{2}, 0.2-\mathrm{mM}$ nucleotides, $0.4 \mu \mathrm{M}$ of primers, $1.25 \mathrm{U}$ of Hot Start Polymerase (Promega Corporation, Fitchburg, WI), 1:10 dilution of template DNA, and water in a 50- $\mu$ l volume. Fragments of the cpn60 gene were amplified using a primer mixture containing a 1:3 M ratio of primers $\mathrm{H} 279 / \mathrm{H} 280$ and primers H1612/H1613 as described by Schellenberg et al. [46]. RNA-dependent RNA polymerase genes were amplified using Illustra Ready-To-Go PCR Beads (GE Healthcare UK Limited, Buckinghamshire, UK), 0.4 $\mu \mathrm{M}$ of primers, $1 \mu \mathrm{l}$ of randomly amplified viral cDNA, and water in a $25-\mu$ l volume. PCR amplicons were run in duplicates, examined in a $1.5 \%$ agarose/0.5X TBE gel stained with $1 \mathrm{X}$ GelRed (Biotium, Inc., Hayward, CA), and purified with a QIAQuick PCR Purification Kit 
Table 2 Description of primers used in PCR and quantitative PCR

\begin{tabular}{|c|c|c|c|c|}
\hline $\begin{array}{l}\text { Target } \\
\text { gene }\end{array}$ & Primer name and sequences $\left(5^{\prime} \rightarrow 3^{\prime}\right)$ & $\begin{array}{l}\text { Amplicon } \\
\text { size (bp) }\end{array}$ & Thermal program & References \\
\hline 18S rRNA & $\begin{array}{l}\text { EUK1A: CTGGTTGATCCTGCCAG } \\
\text { 499R: CACCAGACTTGCCCTCYAAT }\end{array}$ & $\sim 500$ & $\begin{array}{l}94^{\circ} \mathrm{C} \times 5 \mathrm{~min}, 35 \mathrm{cycles} \text { of } 30 \mathrm{~s} \text { at } 94^{\circ} \mathrm{C}, 60 \mathrm{~s} \text { at } 55^{\circ} \mathrm{C} \text {, } \\
\text { and } 90 \mathrm{~s} \text { at } 72{ }^{\circ} \mathrm{C} \text {, and a final cycle of } 10 \mathrm{~min} \text { at } 72{ }^{\circ} \mathrm{C} \text {. }\end{array}$ & {$[40,41]$} \\
\hline ITS & $\begin{array}{l}\text { ITS1: TCCGTAGGTGAACCTGCGG } \\
\text { ITS4: TCCTCCGCTTATTGATATGC }\end{array}$ & $\sim 500$ & $\begin{array}{l}95^{\circ} \mathrm{C} \times 15 \mathrm{~min}, 35 \mathrm{cycles} \text { of } 30 \mathrm{~s} \text { at } 95^{\circ} \mathrm{C}, 30 \mathrm{~s} \text { at } 55^{\circ} \mathrm{C} \text {, } \\
\text { and } 90 \mathrm{~s} \text { at } 72{ }^{\circ} \mathrm{C} \text {, and a final cycle of } 10 \mathrm{~min} \text { at } 72{ }^{\circ} \mathrm{C} \text {. }\end{array}$ & {$[42]$} \\
\hline $\begin{array}{l}\beta \text {-tubulin } \\
\text { (qPCR) }\end{array}$ & $\begin{array}{l}\text { BT107F: AACAACTGGGCIAAGGTYACTACAC } \\
\text { BT261R: ATGAAGAAGTGGAGICGIGGGAA }\end{array}$ & $\sim 450$ & $\begin{array}{l}\text { Initial denaturation } 20 \mathrm{~s} \text { at } 95^{\circ} \mathrm{C} \text {, followed by } 40 \text { cycles } \\
\text { of } 1 \mathrm{~s} \text { at } 95^{\circ} \mathrm{C} \text { and } 30 \mathrm{~s} \text { at } 60^{\circ} \mathrm{C} \text {. }\end{array}$ & [43] \\
\hline $16 \mathrm{~S}$ rRNA & $\begin{array}{l}\text { 341F: CCTACGGGAGGCAGCAG } \\
\text { R806: GGACTACHVGGGTWTCTAAT }\end{array}$ & $\sim 465$ & $\begin{array}{l}94^{\circ} \mathrm{C} \times 5 \mathrm{~min}, 35 \text { cycles of } 45 \mathrm{~s} \text { at } 94^{\circ} \mathrm{C}, 45 \mathrm{~s} \text { at } 50^{\circ} \mathrm{C} \text {, } \\
\text { and } 60 \mathrm{~s} \text { at } 72^{\circ} \mathrm{C} \text {, and a final cycle of } 10 \mathrm{~min} \text { at } 72^{\circ} \mathrm{C} \text {. }\end{array}$ & {$[44,45]$} \\
\hline cpn60 & $\begin{array}{l}\text { H279: GAIIIIGCIGGIGAYGGIACIACIAC } \\
\text { H280: YKIYKITCICCRAAICCIGGIGCYTI } \\
\text { H1612: GAIIIIGCIGGYGACGGYCSACSAC } \\
\text { H1613: CGRCGRTCRCCGAAGCCSGGIGCCTT }\end{array}$ & $\sim 578$ & $\begin{array}{l}3 \text { min at } 94{ }^{\circ} \mathrm{C}, 40 \text { cycles of } 30 \mathrm{~s} \text { at } 94^{\circ} \mathrm{C} \text {, followed by a } \\
\text { temperature gradient of } 1 \mathrm{~min} \text { at } 42^{\circ} \mathrm{C}, 48^{\circ} \mathrm{C}, 54^{\circ} \mathrm{C} \text {, or } \\
60^{\circ} \mathrm{C} \text {, and } 1 \text { min at } 72{ }^{\circ} \mathrm{C} \text {, followed by a final extension } \\
\text { of } 10 \text { min at } 72{ }^{\circ} \mathrm{C} \text {. }\end{array}$ & {$[46]$} \\
\hline $\begin{array}{l}16 S \text { rRNA } \\
\text { (qPCR) }\end{array}$ & $\begin{array}{l}\text { 341F: CCTACGGGAGGCAGCAG } \\
\text { 518R: ATTACCGCGGCTGCTGG }\end{array}$ & $\sim 194$ & $\begin{array}{l}\text { Incubation } 2 \text { min at } 50^{\circ} \mathrm{C} \text {. Initial denaturation } 20 \mathrm{~s} \text { at } \\
95^{\circ} \mathrm{C} \text {, followed by } 40 \text { cycles of } 1 \mathrm{~s} \text { at } 95^{\circ} \mathrm{C} \text { and } 20 \mathrm{~s} \\
\text { at } 60^{\circ} \mathrm{C} \text {. }\end{array}$ & [44] \\
\hline $\begin{array}{l}\text { uidA } \\
\text { (qPCR) }\end{array}$ & $\begin{array}{l}\text { 784F: GTGTGATATCTACCCGCTTCGC } \\
\text { 866R: GAGAACGGTITGTGGTAATCAGGA } \\
\text { EC807: FAM-TCGGCATCCGGTCAGTGGCAGT-BHQ1 }\end{array}$ & 84 & $\begin{array}{l}\text { Incubation } 2 \text { min at } 50{ }^{\circ} \mathrm{C} \text {. Initial denaturation } 10 \text { min } \\
\text { at } 95^{\circ} \mathrm{C} \text {, followed by } 40 \text { cycles of } 15 \mathrm{~s} \text { at } 95^{\circ} \mathrm{C} \\
\text { and } 1 \text { min at } 60{ }^{\circ} \mathrm{C} \text {. }\end{array}$ & [47] \\
\hline $\begin{array}{l}g 23 \\
(q P C R)\end{array}$ & $\begin{array}{l}\text { MZIA1 bis: GATATTTGIGGIGTTCAGCCIATGA } \\
\text { MZIA6: CGCGGTTGATTTCCAGCATGATTTC }\end{array}$ & $\sim 471$ & $\begin{array}{ll}94{ }^{\circ} \mathrm{C} \times 1.5 \mathrm{~min}, 35 \mathrm{cycles} \text { of } 45 \mathrm{~s} & \text { Incubation } 2 \text { min at } 50{ }^{\circ} \mathrm{C} \text {. } \\
\text { at } 94^{\circ} \mathrm{C}, 60 \mathrm{~s} \text { at } 50{ }^{\circ} \mathrm{C} \text {, and } 60 \mathrm{~s} & \text { Initial denaturation for } 20 \mathrm{~s} \\
\text { at } 72{ }^{\circ} \mathrm{C} \text {, and a final cycle of } & \text { at } 95^{\circ} \mathrm{C}, 40 \mathrm{cycles} \text { of } 1 \mathrm{~s} \text { at } \\
5 \mathrm{~min} \text { at } 72{ }^{\circ} \mathrm{C} . & 95^{\circ} \mathrm{C} \text { and } 30 \mathrm{~s} \text { at } 60^{\circ} \mathrm{C} .\end{array}$ & [20] \\
\hline $\operatorname{RdRp}$ & $\begin{array}{l}\text { RdRp1: GGRGAYTACASCIRWTTTGAT } \\
\text { RdRp2: MACCCAACKMCKCTTSARRAA }\end{array}$ & $\sim 450$ & $\begin{array}{l}94^{\circ} \mathrm{C} \times 75 \mathrm{~s}, 40 \text { cycles of } 45 \mathrm{~s} \text { at } 94{ }^{\circ} \mathrm{C}, 45 \mathrm{~s} \text { at } 50{ }^{\circ} \mathrm{C} \text {, and } 60 \mathrm{~s} \\
\text { at } 72{ }^{\circ} \mathrm{C} \text {, and a final cycle of } 5 \mathrm{~min} \text { at } 72^{\circ} \mathrm{C} \text {. }\end{array}$ & {$[26]$} \\
\hline
\end{tabular}

(Qiagen Sciences, Maryland, MD) according to the manufacturer's instructions.

\section{Quantitative polymerase chain reaction of eukaryotes, bacteria, E. coli, and T4-type bacteriophages}

Estimates of eukaryotes, bacteria, E. coli, and T4-type bacteriophage quantities in watershed sites were determined using $\beta$-tubulin, $16 \mathrm{~S}$ rRNA, uidA, and g23 gene fragments, respectively (Table 2). Gene copy numbers were calculated as previously described by Ritalahti et al. [48]. A modification based on sample dilution and volume was introduced to this calculation in terms of GCNs per milliliter sample. Standard curves for qPCR were generated using serial dilutions of linearized pCR2.1-TOPO vector (Life Technologies, Carlsbad, CA) with either cloned $\beta$-tubulin, 16S rRNA, and $g 23$ genes. E. coli genomic DNA was used for standard curves for uidA gene. Each $20-\mu \mathrm{l}$ real-time PCR mixture consisted of $10 \mu \mathrm{l}$ of Fast SYBR Green Master Mix (2X) Real-Time PCR Master Mix, $250 \mathrm{nM}$ of each primer, and $1 \mu \mathrm{l}$ of template DNA. Quantitation of the uidA gene fragment used Taqman Universal PCR Master Mix (Life Technologies, Carlsbad, CA) and followed the conditions, oligonucleotides (400 nM), and probe (200 nM) concentrations described by Maheux et al [49]. SYBR greenlabeled reactions were conducted on a 7900 HT Fast Real-Time PCR system (Life Technologies, Carlsbad, CA), while Taqman-labeled reactions were carried out on a 7500 Fast Real-Time PCR system (Life Technologies, Carlsbad, CA). Each qPCR was run in triplicate. To verify the absence of non-specific amplification, a dissociation step was included in the SYBR green-labeled reactions, and amplicons were visualized on a $1.5 \%$ agarose gel.

\section{DNA library preparation and sequencing}

Libraries of $18 \mathrm{~S}$ rRNA, ITS, $16 \mathrm{~S}$ rRNA, $g 23$, and RdRp amplicons were prepared using the NEXTflex ChIP-Seq Kit (BIOO Scientific, Austin, TX) with the gel-size selection option provided in the manufacturer's instructions. The universal target region of the cpn60 gene was amplified using a 1:3 primer cocktail of H279/H280:H1612/H1613 as previously described by Schellenberg et al. [46].

Bacterial genomic DNA libraries were prepared using the Nextera XT DNA sample preparation kit (Illumina, Inc., San Diego, CA). One nanogram of bacterial DNA was fragmented following the manufacturer's instructions. Libraries from randomly amplified viral DNA and cDNA fractions were prepared using NEXTflex ChIP-Seq kit (BIOO Scientific, Austin, TX) by following a gel-free option provided in the manufacturer's instructions.

Amplicon, bacterial, and viral library sequencing were performed on an Illumina MiSeq (Illumina, Inc., San Diego, CA) using MiSeq reagent kits V2 with 150- and 250-bp paired-end outputs. cpn60 pyrosequencing 
libraries were sequenced on a Roche 454 Genome Sequencer FLX Titanium following standard protocols (Laboratory for Advanced Genome Analysis, Vancouver Prostate Centre). Additionally, PhiX sensu lato, an adapterligated ssDNA virus was used as control in Illumina sequencing. Amplicon libraries used $5 \%$ PhiX, while that for bacterial and viral metagenome libraries used $1 \%$ PhiX.

Amplicon and metagenomic sequencing control genomic DNA from four bacterial strains was used as $16 \mathrm{~S}$ rRNA gene amplicon and metagenomic sequencing control. Bacterial mock community included Nocardioides sp. JS614, Pseudomonas aeruginosa PA01, Rhodobacter capsulatus SB1003, and Streptomyces coelicolor A3. Viral mock community consisting of genomic DNA and cDNA from myovirus and HaRNAV as well as g23 and RdRp amplicons was used as sequencing controls. Bacterial and viral mock communities were pooled in equal molar concentrations, indexed, and sequenced with the environmental samples described in this study. Sequencing controls were not included for the eukaryotic fraction (18S rRNA and ITS).

\section{Data analysis}

Gene copy number (GCN) or flow cytometry count (FCM) data were $\log _{10}$ transformed for analysis. Oneway analysis of variance was run using Statistical Analysis System (SAS, version 9.1.3 for Windows) on the qPCR and FCM data to detect differences among target microbial fractions. Tukey's test was used to determine statistical differences among the different sites. Correlations were assessed using Spearman correlation coefficients. A $p$ value of 0.05 was assumed for the test as a minimum level of significance.

Adapter and primer sequences of amplicon and viral libraries were removed using Cutadapt [50], while short ( $<100 \mathrm{bp}$ )- and low-quality reads were discarded using Trimmomatic version 0.32 [51]. Forward reads of amplicon and viral libraries were uploaded to the Metagenomic Rapid Annotations using Subsystems Technology (MG-RAST) [52] and Metavir [53], respectively. Bacterial amplicon analysis was also performed using QIIME [54] to identify trends robust to analysis platform. The raw data from cpn60 amplicon sequencing was processed through microbial profiling using metagenomic assembly (mPUMA) pipeline [55]. Bacterial metagenome sequence reads were trimmed using Adapter and AdapterRead2 parameters embedded in the MiSeq Reporter software (Illumina, Inc., San Diego, CA). Furthermore, paired-end sequences were merged using PANDAseq [56] and then uploaded to the MG-RAST pipeline [53]. Short $(<151 \mathrm{bp})$ and unmerged bacterial metagenomic reads were discarded.

Taxonomic classifications for eukaryotic and bacterial amplicon and bacteria metagenomic sequence reads were based on the lowest common ancestor method [57]. The MG-RAST bacterial metagenomic results were subsequently confirmed by analysis with MEGAN4 [58]. For viral reads, taxonomic composition was computed using BLASTx from the NCBI website and adjusted via length normalization using the Genome relative Abundance and Average Size (GAAS) Metagenomic Tool [59]. Functional gene composition for bacterial and viral metagenomes was annotated using MG-RAST and the SEED subsystems [60]. A minimum percent identity of $60 \%$ and annotations with an $e$ value cutoff of $10^{-3}$ or less were used for further analyses. Microbial diversity and richness indexes were calculated using EstimateS (version 9.1.0) [61], available from http://viceroy.eeb.uconn.edu/estimates/. Multivariate analysis was performed for bacterial and viral metagenomes and amplicons using the Bray-Curtis metric.

\section{Results and discussion}

Approximately $40 \mathrm{~L}$ of raw water was collected from watershed sites in BC during a 1.5-month period (Spring 2012). A combination of conventional and tangential flow filtration was used to separate eukaryotic-, bacterial-, and viral-sized particles, followed by nucleic acid extraction for these microbial fractions. The utility of the protocol was tested in terms of the quality of the resulting sequence libraries and the ability to characterize the microbial communities. Additional file 1: Table S2 summarizes the water quality parameters measured at each watershed location.

\section{Efficiency of filtration of microbial communities}

Dead end and tangential flow filtration (TFF) have widely been used for the separation of microbial communities in water [26, 32, 62]. A significant correlation (96.1\%, $p \leq 0.0007)$ was observed between viral-like particles and bacterial cell counts by flow cytometry (Additional file 1: Table S3). Flow cytometry counts in raw water detected between $5.03 \times 10^{6}$ and $1.18 \times 10^{8}$ viruslike particles per milliliter of sample, while bacterial counts ranged between $1.55 \times 10^{5}$ and $1.24 \times 10^{6}$ cells/ $\mathrm{mL}$ of environmental water. Virus-like particles were significantly higher $(p<0.0001)$ in APL compared to other watershed locations. Bacterial cell counts in APL were higher compared to watershed locations $(p<0.0001)$, except $\operatorname{ADS}(p=0.4231)$. Overall, TFF was able to achieve a 94-fold concentration of the viral fraction from an initial volume of $\sim 38.7 \mathrm{~L}$ to an average final volume of $415 \mathrm{~mL}$. Viral concentration efficiency averaged $6 \pm 51 \%$ while bacterial concentration efficiency averaged $90 \pm$ $11 \%$. The wide range in viral recovery efficiencies may be associated with losses during filtration [63-65]. Water with high turbidity and suspended solids tend to saturate filters $[66,67]$, and lower recovery efficiencies 
were observed in agricultural samples (APL and ADS), where turbidity and total dissolved solids values were higher (Additional file 1: Table S2).

\section{Ultracentrifugation as a method to improve recovery of viruses}

Assessment of ultracentrifugation to further concentrate viral particles was performed using $\mathrm{qPCR}$ and FCM for adenoviruses and enteroviruses spiked in different volumes of MEM. Comparable recovery efficiencies have been reported with ultracentrifugation $[68,69]$. Additional file 1: Figure S1 depicts quantitation of adenovirus (A) and enterovirus (B) per milliliter sample throughout different stages of the ultracentrifugation process and over time (1, 2 , and $4 \mathrm{~h}$ ). A gradual decrease in terms of viral GCNs and particles per milliliter was observed in supernatants collected at different time points of 1,2 , and $4 \mathrm{~h}$ using both approaches.

Recovery efficiency as measured by $\mathrm{qPCR}$ was estimated to be 54.2 and $68.2 \%$ for adenoviruses and enteroviruses, respectively. Recovery efficiencies were also determined by flow cytometry with average percentages of $160 \pm 26.3 \%$ for adenoviruses and $0.5 \pm 0.1 \%$ for enteroviruses. Correlation analysis between qPCR approach and flow cytometry counts detected coefficients of $0.9206(p=0.0004)$ and $0.8683(p=0.0024)$ for adenoviruses and enteroviruses, respectively (Additional file 1: Figure S2). The observed differences between qPCR and FCM to quantify virus particles for enteroviruses may be associated to FCM underestimating ssRNA viruses $<30 \mathrm{~nm}$ in diameter [70, 71]. In this work, we used Coxsackie B2 enterovirus, which is approximately $30 \mathrm{~nm}$. This may indicate that only a fraction of this enterovirus was measurable by FCM as compared to the qPCR approach. It is also possible that some of these cells containing viruses may have been caught in the $0.2-\mu \mathrm{m}$ filters. This extra step was conducted to filter out cell debris as well as simulate the filtration system used in this research. Although qPCR approach seemed to be more sensitive to detect adenoviruses and enteroviruses in this validation experiment, the lack of a highly conserved viral gene makes the quantitation of viruses difficult compared to other microbial fractions such as bacteria or eukaryotes. Thus, FCM was the method chosen to monitor viral-like particles in water samples. In this study, recovery rates using ultracentrifugation to concentrate virus-like particles in watershed samples and quantified using FCM were between 52.9 and $114.8 \%$ (urban sites, data not shown).

\section{Nucleic acid yields and quality assessment}

Although the nucleic acid yields from this study were compared to other similar studies, direct comparisons are difficult given the differences in water matrix conditions and procedures used (Table S4). Overall nucleic acid yields (excluding viral RNA fraction) had the same order of magnitude across the different filter pore sizes used in this study (Table S4). Total RNA extracted from the viral-sized fraction could only be detected in agricultural sites.

Nucleic acid purity was also estimated (Table S4). The $\mathrm{A}_{260} / \mathrm{A}_{280}$ and $\mathrm{A}_{260} / \mathrm{A}_{230}$ ratios (that indicate potential protein and humic acid contamination) were $>1.4$ and between 0.5 and 2.1, respectively. Similar results have been reported for $A_{260} / A_{280}$ and $A_{260} / A_{230}$ ratios using commercial kits and automated platforms for nucleic acid extraction from environmental samples [72-76]. While the $\mathrm{A}_{260} / \mathrm{A}_{230}$ ratio suggested humic acid contamination, it did not inhibit downstream applications such as PCR, qPCR, random amplification, library preparation, and sequencing.

\section{Amplification and quantitation of microbial fractions Polymerase chain reaction}

The utility of the protocol was tested using a PCR-based targeted sequencing approach for all three fractions. While 18S rRNA and ITS (eukaryotes), 16S rRNA and cpn60 (bacteria), and g23 (T4-type bacteriophage) were detected in all watershed sites, $\mathrm{RdRp}$ amplicons (picornalike viruses) could only be detected in agricultural sites (AUP, APL, and ADS) and the urban downstream site (UDS). Picorna-like viruses have been reported in British Columbia waters and mainly coastal waters infecting eukaryotic phytoplankton [28, 77]. In this study, RdRp fragments were found in watershed sites where dissolved solids and turbidity values were higher compared to other sites (Additional file 1: Table S2). Moreover, in experimental observations, $\mathrm{RdRp}$ fragments have been detected consistently over time in agricultural sites where conductivity and derived parameters such as salinity, specific conductance, and total dissolved solids are relatively higher (data not shown). The detection of these picorna-like viruses in a freshwater environment may also be attributable to terrestrial runoff or excretion by birds and fish $[11,78]$.

\section{Random amplification}

Viral RNA yields were lower compared to the viral DNA, eukaryotic, and bacterial fractions (Table 2). Although viruses are the most abundant entities in the environment, viruses only make up $\sim 5 \%$ of the relative biomass within microbial communities [79]. The small quantities of viral nucleic acids represent a challenge for downstream applications. Large volumes (from tens to hundreds of liters) of water are typically required to isolate and concentrate viral nucleic acids [11, 27, 80, 81]. The average fragment lengths of the amplified viral cDNA and DNA ranged from 200 to $2 \mathrm{~kb}$ with an average length of $400 \mathrm{bp}$ (data not shown), which is similar to other viral studies $[82,83]$. 


\section{Quantitation of microbial fractions}

Quantitative PCR and FCM are powerful culture-independent methods used to quantitate microbial fractions or organisms in a variety of environments. Limitations exist for both approaches in terms of resolution, technical difficulty, variance, and dynamic range [84]. Microbial eukaryotes captured by the filtration system ranged between 1 to $105 \mu \mathrm{m}$ in size, but in this study, a size cutoff of $5 \mu \mathrm{m}$ was used for the larger organisms, suggesting that a significant portion of the microbial eukaryotes would have not been detected by the FCM. Another major constraint of FCM is the difficulty in designing a compatible dye or target-specific antigen for a specific target such as E.coli or T4-like myoviruses. In contrast, qPCR targeting specific genes are much simpler to design and implement. In this study, copy numbers of $\beta$-tubulin, $16 \mathrm{~S}$ rRNA, uidA, and $g 23$ genes were estimated using qPCR (Fig. 1). Due to inaccuracies of DNA measurement by spectrophotometric methods, especially in the presence of inhibitors and contaminants, the GCNs reported in this study rely upon fluorometric measurements using the Qubit instrument (Table S4). As $\beta$-tubulin and 16S rRNA genes are multicopy genes, average factors of $1.93(\beta$ tubulin for eukaryotes) [85, 86] and 4.3 (16S rRNA genes for bacteria) [87] were used to normalize GCNs per nanogram and milliliter sample. The uidA gene is a single copy gene that encodes $\beta$-D-glucuronidase in $E$. coli [88]. Quantitation of major capsid gene fragments for T4-like bacteriophages ( $g 23$ ) was conducted using viral DNA template with no random amplification step. Although the primer sets used to quantify GCNs were specific for these microbial fractions (Table 3), and non-specific amplification was not detected, PCR efficiency was low $(\sim 54 \%)$ for $\beta$-tubulin and $g 23$. This efficiency may have been improved by targeting a smaller DNA fragment (<300 bp); however, amplification of a shorter fragment of $\beta$-tubulin [86] was not successful in our samples, and the hypervariable regions within $g 23$ preclude qPCR of a shorter fragment $[20,89]$.

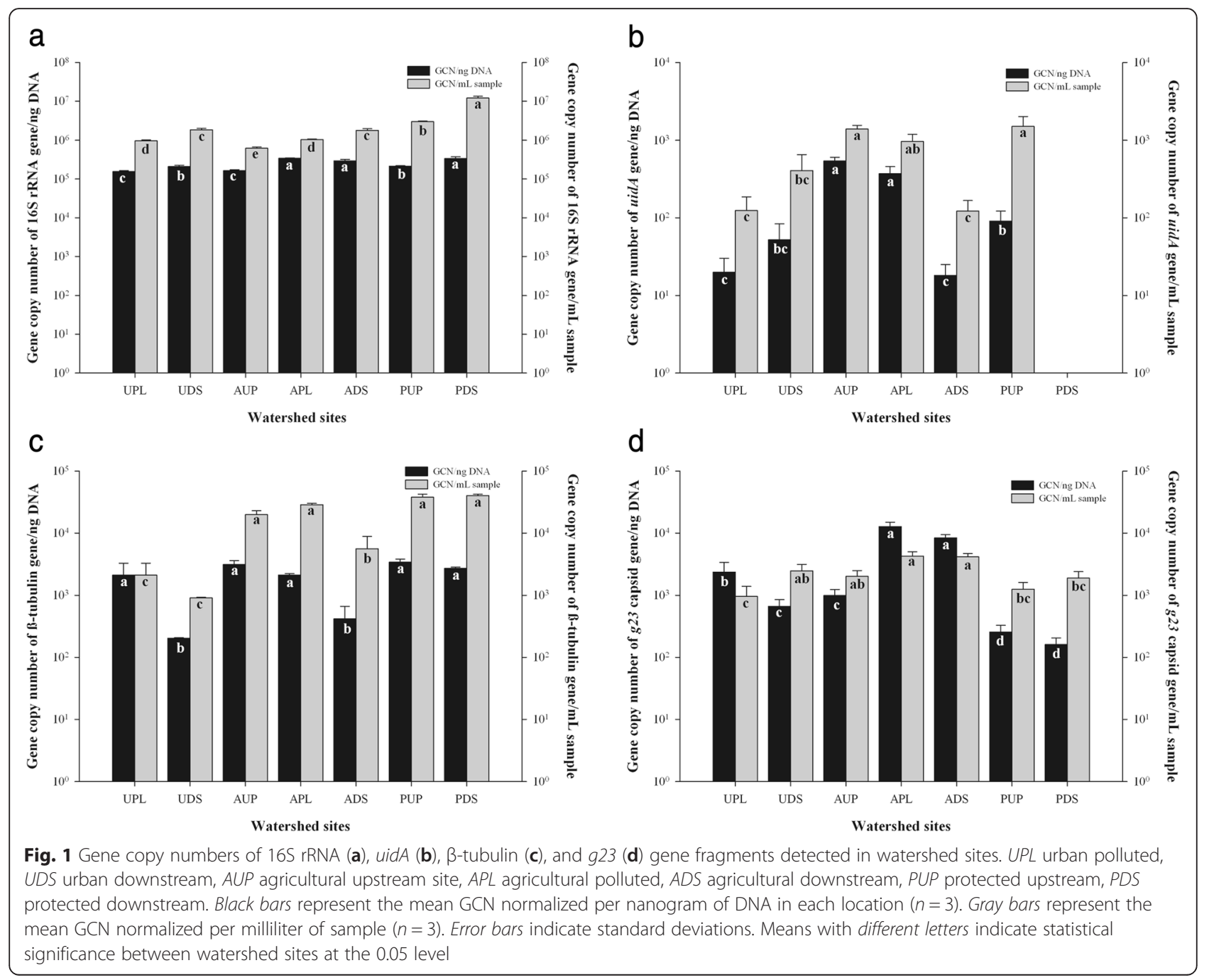


Table 3 Relative abundance (\%) of E. coli in watershed sites using amplicon and metagenome approaches

\begin{tabular}{llll}
\hline Watershed site & 16S rRNA & cpn60* & Bacterial metagenome \\
\hline UPL & $0.71(198854)$ & $0.24(5955)$ & $0.19(44463)$ \\
UDS & $0.65(205568)$ & $0.15(10674)$ & $0.17(70203)$ \\
AUP & $3.95(253363)$ & $2.62(26641)$ & $1.92(48059)$ \\
APL & $0.94(38376)$ & $1.54(43417)$ & $1.43(169295)$ \\
ADS & $0.34(86499)$ & $0.43(53794)$ & $0.44(29399)$ \\
PUP & $1.69(66825)$ & $0.60(8947)$ & $0.06(71837)$ \\
PDS & $0.16(320422)$ & $0.02(11374)$ & $0.42(68525)$
\end{tabular}

Numbers in parentheses represent total number of reads post quality filtering ${ }^{*}$ Correlation coefficients: $16 \mathrm{~S}$ rRNA and cpn60 ( $p$ value $=0.0104, r_{\mathrm{s}}=0.8726$ ); $c p n 60$ and bacterial metagenome ( $p$ value $=0.0018, r_{\mathrm{s}}=0.9374$ )

Estimates of $16 \mathrm{~S}$ rRNA gene abundances (Fig. 1a) were similar to those detected in other aquatic environments [86, 90-93]. The concentrations of prokaryotic cells estimated using $16 \mathrm{~S}$ rRNA gene copies and flow cytometry counts were not significantly correlated $(p>0.05)$. GCNs of the $16 \mathrm{~S}$ rRNA gene per milliliter of sample were between 0.8 to 1.6 orders of magnitude higher compared to FCM counts. Overestimation of prokaryotes by $16 \mathrm{~S}$ rRNA qPCR can be associated with the multicopy nature and intragenomic heterogeneity of $16 \mathrm{~S}$ rRNA [94, 95]. Quantitation of E. coli using the uidA gene (Fig. 1b) indicated that $E$. coli represented only 0.074 and $0.025 \%$ of the biomass (GCN/ng DNA) and volume (GCN/mL of sample), respectively, within the bacterial fraction.

Estimates of eukaryote abundance using the $\beta$-tubulin gene indicated a range between $10^{2}$ to $10^{4}$ organisms across the watershed sites studied (Fig. 1c), which is comparable to previous studies [86, 96-98]. Quantitation of $g 23$ estimated the presence of between $10^{2}$ and $10^{4}$ T4-like bacteriophages per nanogram of DNA and per milliliter of sample (Fig. 1d). As the $g 23$ gene is found in T4-type bacteriophages, these numbers represent only a small fraction of the entire viral community that infects bacteria and an even smaller proportion of the entire viral community. While a comparison between g23 and other viral groups is difficult, quantitation results via qPCR for other DNA viral groups such as adenovirus and JC polyomavirus in other freshwater ecosystems [99] were within the same order of magnitude as our samples.

Variables such as total coliform and E. coli counts, specific conductivity, total dissolved solids, salinity, turbidity, dissolved chloride, ammonia, orthophosphates, nitrites, and nitrates were found to be significantly correlated with $g 23 \mathrm{GCNs} / \mathrm{mL}$ ( $p \leq 0.0280$, data not shown). As these variables increased, the abundance of major capsid genes increased as well. This finding suggests that these environmental variables and enterobacteria may have influence on the viral population, particularly T4- like myoviruses as previously reported in other freshwater ecosystems [100]. No other significant correlations were detected between the other two microbial fractions and environmental parameters.

The ratios of GCNs between $\beta$-tubulin, 16S rRNA, uidA, and $g 23$ were also determined. A ratio of $1: 10^{3}$ was determined for comparison between E. coli (uidA) and total bacteria (16S rRNA gene). A further comparison between total $E$. coli counts (uidA gene fragments) and culturable $E$. coli cells (Colilert) indicated a difference of two to three orders of magnitude higher for quantitation using the uidA gene. This variation between culture-based and molecular-based $E$. coli assays has been previously reported [101]. The ratio of both $\beta$-tubulin and g23 GCNs to $16 \mathrm{~S}$ rRNA GCNs was on average 1:100, similar to other aquatic ecosystems [86, 97, 102-104]. As ecological relationships in aquatic environments are complex, the ratios described here only represent early insights into the microbial community interactions of these watershed locations.

\section{Microbial community structure in watersheds}

Although a small number of samples were analyzed using the Bray-Curtis metric, the protected downstream (PDS) site stood apart from all sites (Additional file 1: Figure S5). Biofilms present in the $8.8-\mathrm{km}$ pipe (Table 2) may have affected the microbial community composition resulting in a distinctive pattern for PDS compared to other watershed locations. The microbial communities not impacted by urban or agricultural activities, such as PUP and AUP, were more similar to one another (Additional file 1: Figure S5). Additional file 1: Tables S5 and S6 summarize read lengths and CG-contents of amplicon and metagenomic libraries, respectively.

Most of the rarefaction curves in the metagenomic and amplicon libraries plateaued (with singleton sequences removed), suggesting that most of the diversity within the eukaryotic, bacterial, and viral communities was captured. Diversity and richness indices were also calculated (Additional file 1: Tables S7 and S8). Although rarefaction curves approached an asymptote, there were differences in terms of community structure in each target fraction across the watershed sites. For instance, APL had the greatest diversity and richness values for bacteria based on the metagenomic data (Additional file 1: Figure S4 and Table S8). However, this community pattern changed when 16S rRNA and cpn60 amplicons were used (Additional file 1: Figure S3 and Table S7). These differences reflect the biases in PCR amplification, multicopy gene abundance, variation in genome sizes, library preparation, and normalization methods [105-107]. Thus, comparisons can only be made between samples prepared and analyzed using the same methods. In the present study, our main goal was to demonstrate the 
utility of a size fractionation method to capture most of the diversity and richness of the microbial community present in these watersheds. Percentage of significant hits assigned to each amplicon and bacterial and viral metagenomes are listed in Additional file 1: Table S9 and further detailed in Additional file 2.

\section{Characterization of microbial eukaryotic communities in watersheds using 18S rRNA and ITS amplicons}

Major taxa identified by $18 \mathrm{~S}$ rRNA sequencing included Chlorophyta, Arthropoda, Streptophyta, Chytridiomycota, Apicomplexa, Nematoda, and Chordata (Fig. 2) while internal transcribed spacer (ITS) sequencing identified major groups such as algae, Chlorophyta, and two fungal phyla, Basidiomcycota and Ascomycota. Streptophyta were detected in the same abundance (16\%) with both 18S rRNA and ITS targets across the sites (Fig. 2). Other taxa detected by ITS sequencing had a lower representation than the same groups measured by $18 \mathrm{~S}$ rRNA. Approximately $20 \%$ of the $18 \mathrm{~S}$ rRNA sequences were assigned as unclassified groups within Eukaryota, with less than $1 \%$ related to fungi. In contrast, $\sim 4.9 \%$ of the ITS sequences were unclassified eukaryotic groups with $50 \%$ of the taxa associated to unclassified fungi. Biases in amplification and sequencing (including sequencing platform) are well described for the 18S rRNA and ITS targets [108-111] and for other microbial targets as well [112]. Overall, Chlorophyta were a dominant group using both $18 \mathrm{~S}$ rRNA and ITS sequencing in the agricultural impacted sites (APL and ADS), while Streptophyta appeared more abundant in urban sites with the $18 \mathrm{~S}$ rRNA sequencing approach. Ascomycota were observed to be dominant in urban sites (UPL and UDS) with the ITS approach compared to other watershed locations. In this study, both $18 \mathrm{~S}$ rRNA and ITS sequencing indicated differences among eukaryotic groups within each watershed.

\section{Characterization of bacterial communities in watersheds}

Abundant phyla of bacteria identified in the watershed samples included the four predominant phyla in the

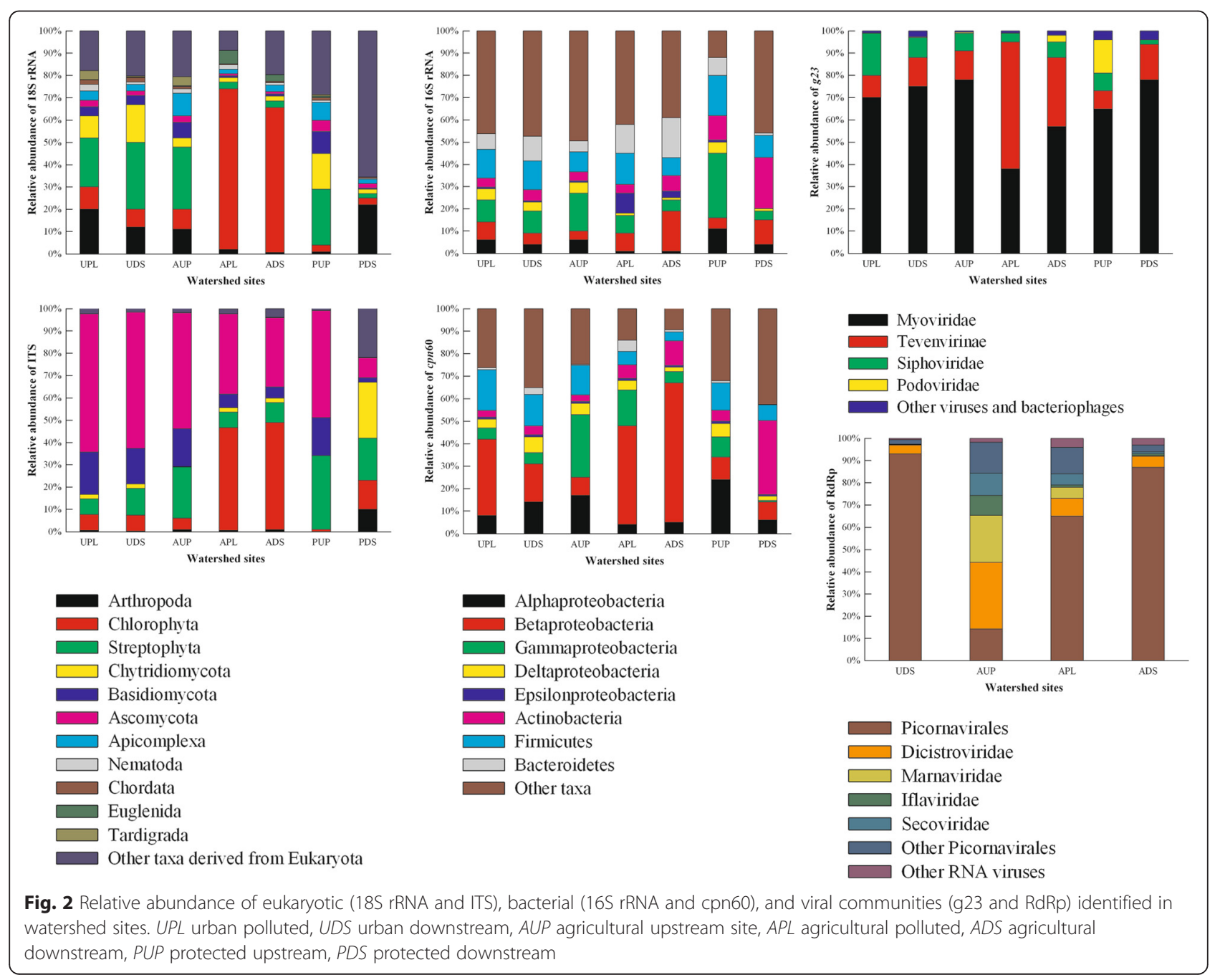


human and wildlife gut and in sediments and soil [113-115]: Proteobacteria (Alpha-, Beta-, Gamma-, Delta-, and Epsilonproteobacteria), Actinobacteria, Firmicutes, and Bacteroidetes (Fig. 3). Betaproteobacteria was the most abundant class of the Proteobacteria and made up $\sim 17,35$, and $11 \%$ of the bacterial community in amplicon and metagenome libraries from urban, agricultural impacted, and protected watersheds, respectively. While this class is a common feature reported in freshwater environments [116], significant differences $(p \leq 0.0184)$ were detected between agricultural and urban sites and protected watersheds.

Of the Firmicutes, order Clostridiales made up $73 \%$ in agricultural impacted watersheds, $68 \%$ in urban impacted watersheds, and $53 \%$ in protected watersheds. Across watersheds, approximately $60 \%$ of Clostridiales belonged to Clostridiaceae family. Other families accounted for $\sim 30 \%$ of the Clostridiales and included Ruminococcaceae, Peptococcaceae, Eubacteriaceae, Lachnospiraceae, and Syntrophomonadaceae. In small percentages ( $\leq 3 \%)$, Heliobacteriaceae, Peptostreptococcaceae, and Clostridiales families XI, XVII, and XVIII were also observed. Interestingly, in agricultural- and urban-impacted watersheds, families such Ruminococcaceae and Lachnospiraceae were observed to be at least onefold higher than in protected sites ( 1.5 \%), while members of Peptostreptococcaceae were completely absent from protected watersheds. Genera of these families have been reported associated to fecal and sewage infrastructures $[12,117]$. Another major order in Firmicutes was Bacillales; estimates of 13,16, and $32 \%$ were observed in agricultural, urban, and protected watersheds, respectively. The majority of Bacillales belonged to Bacillaceae ( 60\%) and
Paenibacillaceae ( $20 \%)$. This abundance of Bacillales in freshwaters is supported by the oxygenated and nonimpacted nature of protected watersheds compared to agricultural or urban watersheds [118].

Both amplicon and metagenomic sequencing also revealed that Actinobacteria had high abundance in protected watersheds ( 20.3\%), particularly PDS ( 32\%) compared to urban (4.5\%) and agricultural (7.0\%) influenced watersheds (Figs. 2 and 3). Although Actinobacteria has routinely been reported as soil bacteria, its occurrence in freshwater and mainly in pristine water bodies could be attributed to soil $\mathrm{pH}[119,120]$. Within this phyla, order Actinomycetales made up $>84 \%$ of Actinobacteria in all watersheds. On average, $16 \%$ of Actinomycetales pertained to Streptomycetaceae in urban and protected watershed, while in agricultural sites, this family represented $5 \%$ or less. A high abundance of bacterial groups within Streptomycetaceae has been associated to the production of geosmin and 2methylisoborneol, which impact water quality $[121,122]$. Other orders included Solirubrobacterales, Rubrobacterales, Acidimicrobiales, Coriobacteriales, and Bifidobacteriales, which made up less than $10 \%$ of the Actinobacterial community in watersheds. Within order Bifidobacteriales, Bifidobacteriaceae (ubiquitous inhabitants of the gastrointestinal tract of mammals) were dominant in urban impacted sites $(\sim 3.4 \%)$ compared to agricultural $(\sim 1.2 \%)$ or protected $(\sim 0.4 \%)$ watersheds.

Although only seven environmental samples were analyzed in this study, a positive correlation $(p \leq 0.05)$ was identified between abundances of Epsilonproteobacteria and Bacteroidetes across watershed sites. Abundances for both classes were found to be higher $(p \leq 0.0476)$ in
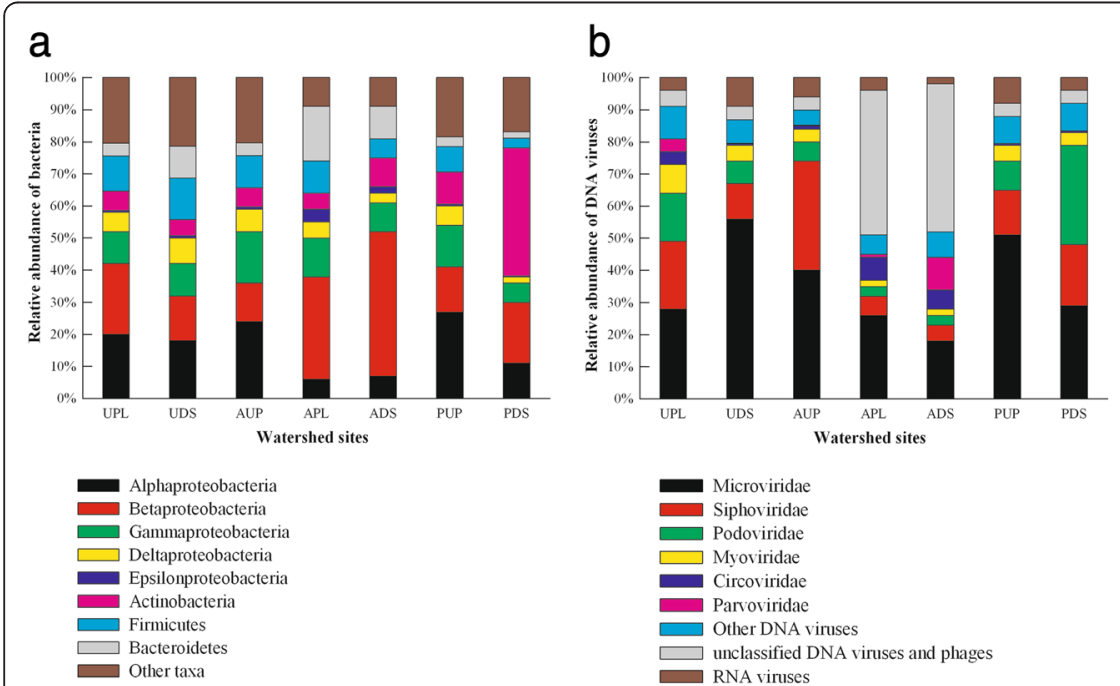

C

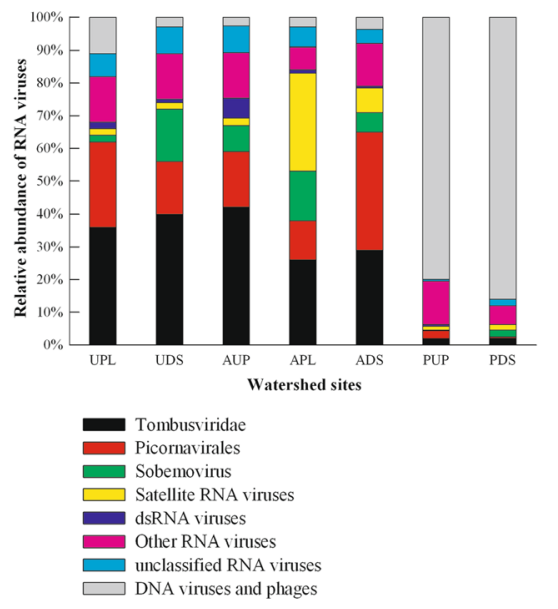

Fig. 3 Relative abundance of bacterial and viral communities characterized using a metagenomic approach in watershed sites. UPL urban polluted, UDS urban downstream, AUP agricultural upstream site, APL agricultural polluted, ADS agricultural downstream, PUP protected upstream, PDS protected downstream. Taxonomic classes of bacteria (a), taxonomic groups of DNA viruses (b), and taxonomic groups of RNA viruses (c) 
agricultural and urban sites compared to protected watersheds. Both of these classes of bacteria have been reported to play an important role in coastal and ocean waters by reducing sulfidic conditions in sediments, anoxic water columns, and oxygen minimum zones [123, 124]. These shifts in bacterial population structure may represent an ecological succession in community structure as a response to the conditions in the impacted watersheds [123].

While relative abundances were used to compensate for library variability and read numbers for each library, clear differences were observed among taxa within the same fraction. For instance, a comparison of taxa abundances generated by the bacterial amplicon and metagenomic sequencing shows that the 16S rRNA amplicon data predict lower abundance of certain bacterial groups, such as Alpha- and Betaproteobacteria, relative to cpn60 and metagenome sequencing (Figs. 2 and 3). In contrast, cpn60 sequencing predicted a lower Bacteroidetes abundance compared to $16 \mathrm{~S}$ rRNA and metagenome sequencing. Moreover, classes such as Planctomycetacia, Chloroflexi, and Verrucomicrobiae represented $~ 50 \%$ of other taxa using cpn60 sequencing, while $16 \mathrm{~S}$ rRNA sequencing identified the same classes in approximately $\leq 1 \%$ among other taxa in most samples.

E. coli, a fecal indicator organism, was further compared with other taxa using amplicon and metagenome sequencing. E. coli abundance is difficult to measure using $16 \mathrm{~S}$ rRNA due to the high $16 \mathrm{~S}$ sequence similarity among genera in the Enterobacteriaceae family. However, significant correlations were detected across sites for E. coli abundance between $16 \mathrm{~S}$ rRNA and cpn60 amplicons $(p=0.0104)$ and cpn60 and metagenomic libraries $(p=0.0018)$ (Table 3). Metagenome data revealed other taxa such as Polynucleobacter, Arcobacter, Methylotenera, Flavobacterium, Pseudomonas, and Bacteroides were found in higher relative abundance compared to $E$. coli in urban and agricultural influenced watersheds. Some of these alternative indicators have been previously reported in urban-impacted watersheds [7]. Polynucleobacter was abundant in amplicon and bacterial metagenome of impaired watersheds. The ubiquity of this genus has been reported in freshwater lakes and rivers associated to ecological diversification $[125,126]$ and may be an indicator of impacted environments.

\section{Characterization of viruses in watersheds}

For DNA virus metagenomic libraries, the rate of taxonomic classification to viral taxa was between $7.81 \%$ (UPL) and $18.89 \%$ (PDS), while for RNA viruses, this number ranged from $1.2 \%$ (UPL) to $17.06 \%$ (APL) (Additional file 1: Table S6). Taxonomic analysis revealed six major groups of DNA viruses and four major groups of RNA viruses (Fig. 3c), with Microviridae and
Tombusviridae being the most well represented groups of DNA and RNA viruses, respectively. The majority of assigned viral DNA sequences $(82 \%)$ corresponded to viruses or phages infecting bacteria such as Microviridae, Siphoviridae, Myoviridae, and unclassified DNA viruses and phages, while $64 \%$ of assigned RNA virus sequences were identified as algal and plant pathogens such as Tombusviridae, Picornavirales, Sobemovirus, and satellite RNA viruses. These families and groups have previously been reported as abundant in other freshwater ecosystems that are rich in organics [73, 127], suggesting trophic status or productivity may influence viral hosts and therefore affect viral community structure. In this context, the remaining groups of DNA viruses included Circoviridae and Parvoviridae, which are known to contain plant and animal viruses [81, 128, 129].

Despite efforts to eliminate DNA from the viral RNA fraction, a significant number of DNA virus sequences were detected in the viral RNA fraction across all sites. These sequences were identified as belonging to groups such as Caudovirales, Circoviridae, Microviridae, classified and unclassified phages infecting prokaryotes, and unclassified ssDNA viruses. A relatively small percentage $(\sim 5 \%)$ of RNA viruses were identified in the viral DNA fraction. Other researchers have also reported DNA and RNA viruses in the opposite fractions $[79,131]$. A probable explanation for these observations may be related to DNA and RNA reverse transcribing viruses combined with representational deficiencies in existing viral database [11, 130, 131].

Sequencing of $g 23$ revealed $\sim 92 \%$ of sequences matched the Myoviridae family including Enterobacteria phages, T4-like viruses, and Klebsiella phages. Moreover, the relative abundance of $\mathrm{RdRp}$ sequences indicated Picornavirales as the most abundant group across sites with JP-B-like viruses accounting for $\sim 90 \%$ of the Picornavirales sequences detected. RdRp amplicons in AUP revealed a more homogeneous distribution of picornalike viruses compared to the other watersheds (Fig. 2). Other members of this picorna-like superfamily were Dicistroviridae, Marnaviridae, Iflaviridae, and Secoviridae, which have been reported as insect and algae-infecting viruses $[11,132]$. Compared to the other microbial fractions, a majority of metagenome viral sequences remained unclassified suggesting that a larger, more complete viral database is needed in order to identify these unknown viruses. These results are largely congruent with other studies in aquatic ecosystems [27, 81, 133, 134], which have also reported a majority of sequences to have unknown origins.

\section{Assessment of community structure among microbial fractions}

Sequencing analysis revealed the presence of larger and smaller organisms within each size fraction, but this 
percentage was minimal within the bacterial and viral DNA fractions. From the bacterial fraction sequencing reads, $96.3 \%$ were associated with bacteria and the remainder classified as Archaea (2.2 \%), Eukaryotes (1.3\%), and viruses comprised less than $0.2 \%$ (not PhiX sensu lato). Ribosomal RNA was detected in viral RNA fraction with percentages ranging from 5.3 to $24.5 \%$. Ribosomal RNA in the viral DNA fraction was found in less than $1 \%$ of the reads. These ribosomal RNAs belonged to bacterial and eukaryotic groups also found in the bacterial metagenome. We hypothesize that free ribosomes from lysed cells (including from the viral lytic cycle) could persist in the environment and would pass through all the filters. Although RNA levels were low or below the detection limit in the viral fraction, the random amplification process could have amplified this material [135]. Also, eluates were not treated with RNase due to the potential degradation of some RNA viruses [81, 136, 137].

Additionally, the Enterobacteria phage PhiX sensu lato, a control used during sequencing, was detected among the viral metagenomic and amplicon libraries, but not in bacterial metagenomic libraries. PhiX contamination averaged $\sim 4 \%$ in the $g 23, \mathrm{RdRp}$, and viral RNA libraries and $\sim 32 \%$ in the viral DNA libraries. This adapter-ligated control was identified in $\sim 0.34 \%$ of the reads in other nonviral amplicon libraries such as ribosomal RNA (18S and 16S rRNA genes) and ITS. Mock communities (bacterial and viral) and amplicons (16S rRNA, $g 23$, and $\mathrm{RdRp}$ ) used as sequencing controls were further analyzed for possible PhiX contamination. Similar to bacterial libraries from environmental samples, no PhiX sensu lato was found in mock bacterial libraries. In viral and amplicon control libraries, less than $1 \%$ of the total reads were assigned to $\mathrm{PhiX}$. A probable explanation may be related to random cluster dispersal that may result in cluster overlap during Illumina sequencing [138]. The high percentage of PhiX in the viral DNA libraries suggests that PhiX (a coliphage) was indeed infecting bacteria such $E$. coli in these samples $[139,140]$. A correlation analysis performed between the abundance of PhiX observed in samples and the relative sequence abundance of E. coli (Table 3) did not detect any significant differences. While the occurrence PhiX sensu lato in viral DNA reads may reflect their actual presence in the environment, reads associated to this bacteriophage were excluded from the results described here as we cannot determine how much could be due to contamination. An alternative approach would have been to skip the addition of PhiX to the libraries or use a different adapter-ligated control in order to corroborate for the presence of these coliphages in the samples.

\section{Gene function analysis and composition}

Besides improving to taxonomic analysis, metagenomic sequencing has the advantage of enabling the analysis of

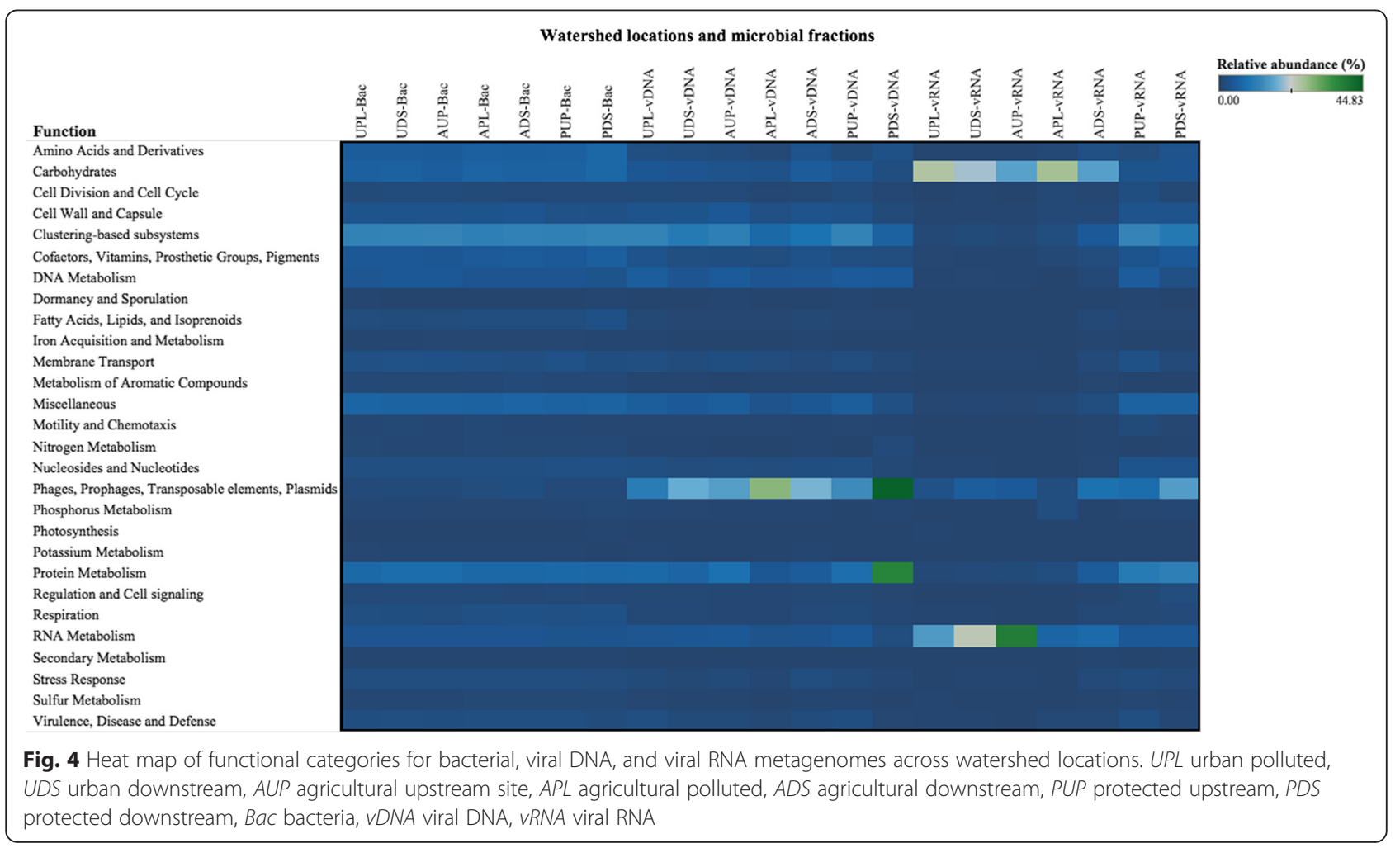


the functional gene content of the microbial community. Comparison of gene function abundances in the bacterial fraction using SEED subsystem classifications revealed no major differences across sites (Fig. 4). Genes with unknown function that are hypothesized to have similar functions based on their locations across genomes (clustering-based subsystems) made up most of the bacterial annotations $(\sim 12.23 \%)$, followed by genes involved in protein metabolism ( 7.35\%). Phage-associated genes, including those coding for capsid proteins and terminases, were the most abundant functional annotations in the viral DNA fraction (Fig. 4). These genes are major components of the phage DNA packaging machinery $[141,142]$. Notably, in the RNA fraction, retron-type reverse transcriptase genes (RNA metabolism category) were found in higher relative abundance in AUP and urban sites compared to other sites (Fig. 4). This reverse flow of genes is considered a fingerprint of viral replication in any system [143].

As parasites of their hosts, viruses enter and hijack natural cellular process [144]. Universal glycoproteins such as GTPases made up significant proportions of the protein metabolism within the viral DNA fraction. Higher abundance of genes involved in carbohydrate metabolism (mainly ribokinases) was observed within the viral RNA fraction. The acquisition of cellular genes may reflect host-defense mechanisms against viruses and utilization of the host machinery for the viruses to replicate. Consistent with the findings from the taxonomic characterization, where DNA viruses were found in the viral RNA fraction, analysis of putative functions revealed DNA virus-associated genes (encoding for phage capsids and scaffolds) in some of the viral RNA samples.

Overall, a wide variety of taxa and genes were predicted using amplicon and metagenomic approaches. As discussed above, this variability in microbial communities can be attributed to a combination of the survey methods, organism/particle sizes, anthropogenic affects, and environmental conditions.

\section{Conclusion}

We have developed a method for separating different sized microorganisms (eukaryotes, bacteria, and viruses) from water samples and comprehensive characterization of the water microbiota. So far, few studies have attempted to characterize multiple microbial domains from the same environmental sample due to technical challenges, the effort required, and the cost. The use of a systematic size fractionation approach enabled enrichment of a particular fraction and minimized noise during metagenomic sequencing from larger fractions to the smaller ones. While multiple associations were observed between classes and sites, we have highlighted only the most representative findings as the focus was to develop a robust methodology for extensive watershed microbiome analysis. The use of metagenomics to characterize microbial communities provides insights not only into the wider range of microbial eukaryotic, bacteria, and viral taxa present in watersheds but also for further analysis of the functional gene complement in these microbial communities. Note that a large proportion of viral amplicon and metagenomic sequence data remained unassigned, supporting the need for further study of viral diversity and development of viral sequence databases for reference-based analysis. A year-long, large-scale watershed metagenomic project (http://www.ncbi.nlm. nih.gov/bioproject/287840) has employed the methods described here, and this report describes the early findings from this study. This larger project aims to further characterize profiles of microbial eukaryotes, bacteria, and viruses, combined with physical, chemical, and biological indicator data, in multiple watersheds in British Columbia with the ultimate goal of discovering new biomarkers to monitor water quality. We hope that the methods described here and the accompanying preliminary data will support other similar holistic analyses of water microbial communities and not only improve our understanding of the complexities of the water microbiome but also further our ability to protect our watersheds.

\section{Additional files}

Additional file 1: Word document includes table of contents for supplemental results, discussion, and detailed methods. Supplemental tables (Tables S1-S9) and figures (Figures S1-S5) are also included. (DOCX 785 kb)

Additional file 2: Excel file contains output data from MG-RAST, mPUMA, and MetaVir reported in this study. Singletons have been removed from the analysis. (XLSX $1941 \mathrm{~kb})$

\section{Abbreviations}

cpn60: chaperonin-60; FCM: flow cytometry; GCN: gene copy number; ITS: internal transcribed spacer; g23: major capsid gene; qPCR: quantitative PCR; RdRp: RNA-dependent RNA polymerase; rRNA: ribosomal RNA; TFF: tangential flow filtration.

\section{Competing interests}

The authors declare that they have no competing interests.

\section{Authors' contributions}

MUD performed the experiments, analyzed the data, prepared the figures and/or tables, and wrote and reviewed the drafts of the manuscript. MC performed the experiments and reviewed the drafts of the manuscript. BLC conducted cpn60 amplicon generation, analyzed the data, and reviewed the drafts of the manuscript. MAC analyzed the data, contributed the analysis tools, and reviewed the drafts of the manuscript. JFF performed the experiments, analyzed the data, and reviewed the drafts of the manuscript. MAP contributed the analysis tools and reviewed the drafts of the manuscript. TVR contributed the analysis tools, prepared the table, and reviewed the drafts of the manuscript. JEH, CAS, FSLB, JIR, NAP, and PKCT designed the experiments, contributed the analysis tools, and reviewed the drafts of the manuscript. All authors read and approved the final manuscript. 


\section{Acknowledgements}

A special acknowledgement to Brian Auk, Belinda Wong, and the staff members in the Environmental Microbiology Laboratory at the BC Public Health Laboratory (BCPHL) for their advice and support. The authors would like to thank Dr. William Hsiao, Dr. Martin Petric, Dr. Iris Luo, Kirby Cronin, Vincent Montoya, Louella D'Silva, David Lawrence from BCPHL, and Raymond Lo from Simon Fraser University (SFU) for their help with the sample collection, experimental controls, sample processing, and qPCR data. We also thank Alan McNabb and the staff members in the Molecular Microbiology and Genomics Program at the BCPHL for their PCR and sequencing expertise. A special acknowledgement to Majid HojjatiNajafabadi (SFU) for his help with the Tableau software license (version 9.0).

\section{Funding}

This work was funded by Genome BC and Genome Canada grant no. LSARP-165WAT, with major support from the Simon Fraser University Community Trust Endowment Fund and additional support from the Public Health Agency of Canada. MUD was supported by a Mitacs Accelerate fellowship. TVR is supported by an NSERC Canada Graduate scholarship, and MAP has been supported by scholarships from the CIHR/MSFHR Bioinformatics Training Program and NSERC.

\section{Author details}

'British Columbia Public Health Laboratory, British Columbia Centre for Disease Control, Vancouver, BC V5Z 4R4, Canada. ${ }^{2}$ South Kensington Campus, Imperial College London, Sir Ernst Chain Building, London SW7 2AZ, UK. ${ }^{3}$ Department of Earth, Ocean and Atmospheric Sciences, University of British Columbia, Vancouver, BC V6T 1Z4, Canada. ${ }^{4}$ Department of Microbiology and Immunology, University of British Columbia, Vancouver, BC V6T 1Z4, Canada. ${ }^{5}$ Department of Botany, University of British Columbia, Vancouver, BC V6T 1Z4, Canada. ${ }^{6}$ Department of Veterinary Microbiology, Western College of Veterinary Medicine, University of Saskatchewan, Saskatoon, SK S7N 5B4, Canada. 'Department of Molecular Biology and Biochemistry, South Science Building, Simon Fraser University, Burnaby, BC V5A 156, Canada. ${ }^{8}$ Integrated Microbial Biodiversity Program, Canadian Institute for Advanced Research, Toronto, ON M5G 1Z8, Canada. ${ }^{9}$ Department of Pathology and Laboratory Medicine, Faculty of Medicine, University of British Columbia, Vancouver, BC V6T 1Z4, Canada. ${ }^{10}$ Department of Pathology, Sidra Medical and Research Center, PO Box 26999, Doha, Qatar.

Received: 17 November 2015 Accepted: 4 April 2016

Published online: 11 July 2016

\section{References}

1. Hinrichsen D. Feeding a future world. People Planet. 1998;7(1):6-9.

2. Vorosmarty CJ, McIntyre PB, Gessner MO, Dudgeon D, Prusevich A, Green P, et al. Global threats to human water security and river biodiversity. Nature. 2010;467(7315):555-61.

3. Elmhagen B, Destouni $G$, Angerbjörn A, Borgström S, Boyd E, Cousins SAO, et al. Interacting effects of change in climate, human population, land use, and water use on biodiversity and ecosystem services. Ecol Soc. 2015;20(1):23.

4. Boubetra A, Le Nestour F, Allaert C, Feinberg M. Validation of alternative methods for the analysis of drinking water and their application to Escherichia coli. Appl Environ Microbiol. 2011;77(10):3360-7.

5. Ward DM, Weller R, Bateson MM. 165 rRNA sequences reveal numerous uncultured microorganisms in a natural community. Nature. 1990;345(6270):63-5

6. Schloss PD, Handelsman J. Metagenomics for studying unculturable microorganisms: cutting the Gordian knot. Genome Biol. 2005;6(8):229.

7. Sonthiphand P, Cejudo E, Schiff SL, Neufeld JD. Wastewater effluent impacts ammonia-oxidizing prokaryotes of the Grand River, Canada. Appl Environ Microbiol. 2013;79(23):7454-65

8. Lee JE, Lee S, Sung J, Ko G. Analysis of human and animal fecal microbiota for microbial source tracking. ISME J. 2011;5(2):362-5

9. Needham DM, Chow CE, Cram JA, Sachdeva R, Parada A, Fuhrman JA. Short-term observations of marine bacterial and viral communities: patterns, connections and resilience. ISME J. 2013;7(7):1274-85.

10. Chow CE, Kim DY, Sachdeva R, Caron DA, Fuhrman JA. Top-down controls on bacterial community structure: microbial network analysis of bacteria, T4-like viruses and protists. ISME J. 2014;8(4):816-29.
11. Culley Al, Mueller JA, Belcaid M, Wood-Charlson EM, Poisson G, Steward GF. The characterization of RNA viruses in tropical seawater using targeted PCR and metagenomics. mBio. 2014;5(3):e01210-4.

12. Wu CH, Sercu B, Van de Werfhorst LC, Wong J, DeSantis TZ, Brodie EL, et al. Characterization of coastal urban watershed bacterial communities leads to alternative community-based indicators. PLoS ONE. 2010;5(6):e11285.

13. Damashek J, Smith JM, Mosier AC, Francis CA. Benthic ammonia oxidizers differ in community structure and biogeochemical potential across a riverine delta. Front. Microbiol. 2014;5:743.

14. Staley C, Gould TJ, Wang P, Phillips J, Cotner JB, Sadowsky MJ. Core functional traits of bacterial communities in the Upper Mississippi River show limited variation in response to land cover. Front Microbiol. 2014;5:414.

15. Fisher JC, Newton RJ, Dila DK, McLellan SL. Urban microbial ecology of a freshwater estuary of Lake Michigan. Elem Sci Anth. 2015;3:000064.

16. Zhang T, Breitbart M, Lee WH, Run JQ, Wei CL, Soh SW, et al. RNA viral community in human feces: prevalence of plant pathogenic viruses. PLoS Biol. 2006:4(1), e3.

17. Rosario K, Symonds EM, Sinigalliano C, Stewart J, Breitbart M. Pepper mild mottle virus as an indicator of fecal pollution. Appl Environ Microbiol. 2009;75(22):7261-7.

18. Gourmelon M, Caprais MP, Le Mennec C, Mieszkin S, Ponthoreau C, Gendronneau M. Application of library-independent microbial source tracking methods for identifying the sources of faecal contamination in coastal areas. Water Sci Technol. 2010;61(6):1401-9.

19. Fierer N, Breitbart M, Nulton J, Salamon P, Lozupone C, Jones R, Robeson M, Edwards RA, Felts B, Rayhawk S, Knight R, Rohwer F, Jackson RB. Metagenomic and small-subunit rRNA analyses reveal the genetic diversity of bacteria, archaea, fungi, and viruses in soil. Appl Environ Microbiol. 2007;73(21):7059-66.

20. Filée J, Tétart F, Suttle CA, Krisch HM. Marine T4-type bacteriophages, a ubiquitous component of the dark matter of the biosphere. Proc Natl Acad Sci U S A. 2005;102(35):12471-6.

21. Wang GH, Yu ZH, Liu JJ, Jin JA, Liu XB, Kimura M. Molecular analysis of the major capsid genes (g23) of T4-type bacteriophages in an upland black soil in Northeast China. Biol Fertil Soils. 2011;47(3):273-82.

22. Chow CE, Fuhrman JA. Seasonality and monthly dynamics of marine myovirus communities. Environ Microbiol. 2012;14(8):2171-83.

23. Zheng C, Wang G, Liu J, Song C, Gao H, Liu X. Characterization of the major capsid genes (g23) of T4-type bacteriophages in the wetlands of northeast China. Microb Ecol. 2013;65(3):616-25.

24. Adriaenssens EM, Cowan DA. Using signature genes as tools to assess environmental viral ecology and diversity. Appl Environ Microbiol. 2014:80(15):4470-80.

25. Ahlquist P. RNA-dependent RNA polymerases, viruses, and RNA silencing. Science. 2002;296(5571):1270-3.

26. Culley AI, Lang AS, Suttle CA. Metagenomic analysis of coastal RNA virus communities. Science. 2006;312(5781):1795-8.

27. Culley Al, Suttle CA, Steward GF. Characterization of the diversity of marine RNA viruses. Limnol Oceanogr Methods. 2010;19:193-201.

28. Gustavsen JA, Winget DM, Tian X, Suttle CA. High temporal and spatial diversity in marine RNA viruses implies that they have an important role in mortality and structuring plankton communities. Front Microbiol. 2014:5:703.

29. APHA. In: Eaton AD, Clesceri LS, Rice EW, Greenberg AE, editors. Standard methods for the examination of water and wastewater, Chapter 38. Maryland: American Public Health Association; 2005. p. 4-67-68. 64-117-118.

30. Murphy J, Riley JP. A modified single solution method for the determination of phosphate in natural waters. Anal Chim Acta. 1962;27:31-6.

31. Wood ED, Armstrong FAJ, Richards FA. Determination of nitrate in sea water by cadmium-copper reduction to nitrite. J Mar Biolog Assoc UK. 1967:47(1):23-31.

32. Suttle CA, Chan AM, Cottrell MT. Use of ultrafiltration to isolate viruses from seawater which are pathogens of marine phytoplankton. Appl Environ Microbiol. 1991:57(3):721-6.

33. Brussaard CP. Optimization of procedures for counting viruses by flow cytometry. Appl Environ Microbiol. 2004;70(3):1506-13.

34. Vaulot D. CYTOPC: processing software for flow cytometric data. Signal Noise. 1989:2:8

35. Wong $\mathrm{S}$, Pabbaraju $\mathrm{K}$, Pang $\mathrm{XL}$, Lee $\mathrm{BE}$, Fox JD. Detection of a broad range of human adenoviruses in respiratory tract samples using a sensitive multiplex real-time PCR assay. J Med Virol. 2008;80(5):856-65. 
36. Verstrepen WA, Kuhn S, Kockx MM, Van De Vyvere ME, Mertens AH. Rapid detection of enterovirus RNA in cerebrospinal fluid specimens with a novel single-tube real-time reverse transcription-PCR assay. J Clin Microbiol. 2001;39(11):4093-6.

37. Watzinger F, Suda M, Preuner S, Baumgartinger R, Ebner K, Baskova L, et al. Real-time quantitative PCR assays for detection and monitoring of pathogenic human viruses in immunosuppressed pediatric patients. J Clin Microbiol. 2004:42(11):5189-98.

38. Ruecker NJ, Bounsombath N, Wallis P, Ong CS, Isaac-Renton JL, Neumann NF. Molecular forensic profiling of Cryptosporidium species and genotypes in raw water. Appl Environ Microbiol. 2005;71(12):8991-4

39. Wang D, Coscoy L, Zylberberg M, Avila PC, Boushey HA, Ganem D, et al. Microarray-based detection and genotyping of viral pathogens. Proc Natl Acad Sci U S A. 2002;99(24):15687-92.

40. Amann RI, Krumholz L, Stahl DA. Fluorescent-oligonucleotide probing of whole cells for determinative, phylogenetic, and environmental studies in microbiology. J Bacteriol. 1990;172(2):762-70.

41. Zhu F, Massana R, Not F, Marie D, Vaulot D. Mapping of picoeucaryotes in marine ecosystems with quantitative PCR of the $18 \mathrm{~S}$ rRNA gene. FEMS Microbiol Ecol. 2005;52(1):79-92.

42. White TJ, Bruns T, Lee S, Taylor J. Amplification and direct sequencing of fungal ribosomal RNA genes for phylogenetics. In: Innis MA, Gelfand DH, Shinsky JJ, White TJ, editors. PCR protocols: a guide to methods and applications, Chapter 38. New York: Academic; 1990. p. 315-22.

43. Baker BJ, Lutz MA, Dawson SC, Bond PL, Banfield JF. Metabolically active eukaryotic communities in extremely acidic mine drainage. Appl Environ Microbiol. 2004;70(10):6264-71

44. Muyzer G, de Waal EC, Uitterlinden AG. Profiling of complex microbial populations by denaturing gradient gel electrophoresis analysis of polymerase chain reaction-amplified genes coding for $16 \mathrm{~S}$ rRNA. Appl Environ Microbiol. 1993;59(3):695-700.

45. Caporaso JG, Lauber CL, Walters WA, Berg-Lyons D, Lozupone CA, Turnbaugh PJ, et al. Global patterns of 165 rRNA diversity at a depth of millions of sequences per sample. Proc Natl Acad Sci U S A. 2011;108 Suppl 1:4516-22.

46. Schellenberg J, Links MG, Hill JE, Hemmingsen SM, Peters GA, Dumonceaux TJ. Pyrosequencing of chaperonin-60 (cpn60) amplicons as a means of determining microbial community composition. Methods Mol Biol. 2011;733:143-58.

47. Frahm E, Obst U. Application of the fluorogenic probe technique (TaqMan P(R) to the detection of Enterococcus spp. and Escherichia coli in water samples. J Microbiol Methods. 2003;52(1):123-31.

48. Ritalahti KM, Amos BK, Sung Y, Wu Q, Koenigsberg SS, Loffler FE. Quantitative PCR targeting 165 rRNA and reductive dehalogenase genes simultaneously monitors multiple Dehalococcoides strains. Appl Environ Microbiol. 2006;72(4):2765-74.

49. Maheux AF, Bissonnette L, Boissinot M, Bernier JL, Huppe V, Picard FJ, et al. Rapid concentration and molecular enrichment approach for sensitive detection of Escherichia coli and Shigella species in potable water samples. Appl Environ Microbiol. 2011;77(17):6199-207.

50. Martin M. Cutadapt removes adapter sequences from high-throughput sequencing reads. EMBnetjournal. 2011;17(1):10-2.

51. Bolger AM, Lohse M, Usadel B. Trimmomatic: a flexible trimmer for Illumina sequence data. Bioinformatics. 2014;30(15):2114-20.

52. Meyer F, Paarmann D, D'Souza M, Olson R, Glass EM, Kubal M, et al. The metagenomics RAST server-a public resource for the automatic phylogenetic and functional analysis of metagenomes. BMC Bioinformatics. 2008;9:386.

53. Roux S, Tournayre J, Mahul A, Debroas D, Enault F. Metavir 2: new tools for viral metagenome comparison and assembled virome analysis. BMC Bioinformatics. 2014;15:76.

54. Caporaso JG, Kuczynski J, Stombaugh J, Bittinger K, Bushman FD, Costello EK, et al. QIIME allows analysis of high-throughput community sequencing data. Nat Methods. 2010;7:335-6.

55. Links MG, Chaban B, Hemmingsen SM, Muirhead K, Hill JE. mPUMA: a computational approach to microbiota analysis by de novo assembly of operational taxonomic units based on protein-coding barcode sequences. Microbiome. 2013;1:23

56. Masella AP, Bartram AK, Truszkowski JM, Brown DG, Neufeld JD. PANDAseq: paired-end assembler for Illumina sequences. BMC Bioinformatics. 2012;13:31.
57. Huson DH, Auch AF, Qi J, Schuster SC. MEGAN analysis of metagenomic data. Genome Res. 2007;17(3):377-86.

58. Huson DH, Mitra S, Ruscheweyh HJ, Weber N, Schuster SC. Integrative analysis of environmental sequences using MEGAN4. Genome Res. 2011;21(9):1552-60.

59. Angly FE, Willner D, Prieto-Davo A, Edwards RA, Schmieder R, Vega-Thurber $R$, et al. The GAAS metagenomic tool and its estimations of viral and microbial average genome size in four major biomes. PLoS Comput Biol. 2009;5(12), e1000593.

60. Overbeek R, Begley T, Butler RM, Choudhuri JV, Diaz N, Chuang H-Y, et al. The subsystems approach to genome annotation and its use in the project to annotate 1000 genomes. Nucleic Acids Res. 2005;33(17):5691-702.

61. Colwell RK, Estimate S. Statistical estimation of species richness and shared species from samples. 2013. Version 9.1.0. Available: http://viceroy.eeb. uconn.edu/estimates/. Access: 17-18 Aug 2015.

62. Wang Y, Hammes F, Boon N, Egli T. Quantification of the filterability of freshwater bacteria through $0.45,0.22$, and $0.1 \mu \mathrm{m}$ pore size filters and shape-dependent enrichment of filterable bacterial communities. Environ Sci Technol. 2007:41(20):7080-6.

63. Winget DM, Williamson KE, Helton RR, Wommack KE. Tangential flow diafiltration: an improved technique for estimation of virioplankton production. Aquat Microb Ecol. 2005;41(3):221-32.

64. Colombet J, Robin A, Lavie L, Bettarel Y, Cauchie HM, Sime-Ngando T. Virioplankton 'pegylation': use of PEG (polyethylene glycol) to concentrate and purify viruses in pelagic ecosystems. J Microbiol Methods. 2007;71(3):212-9.

65. Schoenfeld T, Patterson M, Richardson PM, Wommack KE, Young M, Mead D. Assembly of viral metagenomes from yellowstone hot springs. Appl Environ Microbiol. 2008;74(13):4164-74.

66. Karim MR, Rhodes ER, Brinkman N, Wymer L, Fout GS. New electropositive filter for concentrating enteroviruses and noroviruses from large volumes of water. Appl Environ Microbiol. 2009;75(8):2393-9.

67. Aslan A, Xagoraraki I, Simmons FJ, Rose JB, Dorevitch S. Occurrence of adenovirus and other enteric viruses in limited-contact freshwater recreational areas and bathing waters. J Appl Microbiol. 2011;111(5):1250-61.

68. Steward GF, Montiel JL, Azam F. Genome size distributions indicate variability and similarities among marine viral assemblages from diverse environments. Limnol Oceanogr. 2000;45(8):1697-706.

69. Prata C, Ribeiro A, Cunha A, Gomes NCM, Almeida A. Ultracentrifugation as a direct method to concentrate viruses in environmental waters: virus-like particle enumeration as a new approach to determine the efficiency of recovery. J Environ Monit. 2012;14(1):64-70.

70. Brussaard CP. Viral control of phytoplankton populations-a review. J Eukaryot Microbiol. 2004;51(2):125-38

71. Tomaru Y, Nagasaki K. Flow cytometric detection and enumeration of DNA and RNA viruses infecting marine eukaryotic microalgae. J Oceanogr. 2007;63(2):215-21

72. Burgener $\mathrm{M}$, Candrian U, Gilgen M. Comparative evaluation of four large-volume RNA extraction kits in the isolation of viral RNA from water samples. J Virol Methods. 2003;108(2):165-70.

73. Rutjes SA, Italiaander R, van den Berg HH, Lodder WJ, de Roda Husman AM. Isolation and detection of enterovirus RNA from large-volume water samples by using the NucliSens miniMAG system and real-time nucleic acid sequence-based amplification. Appl Environ Microbiol. 2005;71(7):3734-40.

74. Bey BS, Fichot EB, Dayama G, Decho AW, Norman RS. Extraction of high molecular weight DNA from microbial mats. BioTechniques. 2010;49(3):631-40.

75. Bey BS, Fichot EB, Norman RS. Extraction of high molecular weight DNA from microbial mats. J Vis Exp. 2011:53, e2887.

76. Metcalf $D$, Weese JS. Evaluation of commercial kits for extraction of DNA and RNA from Clostridium difficile. Anaerobe. 2012;18(6):608-13.

77. Culley Al, Lang AS, Suttle CA. The complete genomes of three viruses assembled from shotgun libraries of marine RNA virus communities. Virol J. 2007:4:69

78. Djikeng A, Kuzmickas R, Anderson NG, Spiro DJ. Metagenomic analysis of RNA viruses in a fresh water lake. PLoS ONE. 2009:4(9), e7264.

79. Suttle CA. Marine viruses-major players in the global ecosystem. Nat Rev Microbiol. 2007;5(10):801-12.

80. Breitbart M, Salamon P, Andresen B, Mahaffy JM, Segall AM, Mead D, et al. Genomic analysis of uncultured marine viral communities. Proc Natl Acad Sci U S A. 2002;99(22):14250-5. 
81. Rosario K, Nilsson C, Lim YW, Ruan Y, Breitbart M. Metagenomic analysis of viruses in reclaimed water. Environ Microbiol. 2009;11(11):2806-20.

82. Rohwer F, Seguritan V, Choi DH, Segall AM, Azam F. Production of shotgun libraries using random amplification. BioTechniques. 2001;31(1):108-18.

83. Winget DM, Wommack KE. Randomly amplified polymorphic DNA PCR as a tool for assessment of marine viral richness. Appl Environ Microbiol. 2008;74(9):2612-8

84. Loftie-Eaton W, Tucker A, Norton A, Top EM. Flow cytometry and real-time quantitative PCR as tools for assessing plasmid persistence. Appl Environ Microbiol. 2014;80(17):5439-46.

85. Katz W, Weinstein B, Solomon F. Regulation of tubulin levels and microtubule assembly in Saccharomyces cerevisiae: consequences of altered tubulin gene copy number. Mol Cell Biol. 1990;10(10):5286-94.

86. Holmes DE, Giloteaux L, Williams KH, Wrighton KC, Wilkins MJ, Thompson $\mathrm{CA}$, et al. Enrichment of specific protozoan populations during in situ bioremediation of uranium-contaminated groundwater. ISME J. 2013;7(7):1286-98

87. Lee ZM, Bussema CIII, Schmidt TM. rrnDB: documenting the number of rRNA and tRNA genes in bacteria and archaea. Nucleic Acids Res. 2009;37(Database issue):D489-93.

88. Martins MT, Rivera IG, Clark DL, Stewart MH, Wolfe RL, Olson BH. Distribution of uidA gene sequences in Escherichia coli isolates in water sources and comparison with the expression of $\beta$-glucuronidase activity in 4-methylumbelliferyl- $\beta$-D-glucuronide media. Appl Environ Microbiol. 1993;59(7):2271-6.

89. Hambly E, Tetart F, Desplats C, Wilson WH, Krisch HM, Mann NH. A conserved genetic module that encodes the major virion components in both the coliphage T4 and the marine cyanophage S-PM2. Proc Natl Acad Sci U S A. 2001;98(20):11411-6.

90. Mieszkin S, Furet JP, Corthier G, Gourmelon M. Estimation of pig fecal contamination in a river catchment by real-time PCR using two pig-specific Bacteroidales 16S rRNA genetic markers. Appl Environ Microbiol. 2009;75(10):3045-54.

91. Czekalski N, Berthold T, Caucci S, Egli A, Bürgmann H. Increased levels of multiresistant bacteria and resistance genes after wastewater treatment and their dissemination into Lake Geneva. Switzerland Front Microbiol. 2012;3:106.

92. Heinrich F, Eiler A, Bertilsson S. Seasonality and environmental control of freshwater SAR11 (LD12) in a temperate lake (Lake Erken, Sweden). Aquat Microb Ecol. 2013;70(1):33-44.

93. Holmes DE, Giloteaux L, Barlett M, Chavan MA, Smith JA, Williams KH, et al. Molecular analysis of the in situ growth rates of subsurface Geobacter species. Appl Environ Microbiol. 2013;79(5):1646-53.

94. Pei AY, Oberdorf WE, Nossa CW, Agarwal A, Chokshi P, Gerz EA, et al. Diversity of 16S rRNA genes within individual prokaryotic genomes. Appl Environ Microbiol. 2010;76(12):3886-97.

95. Sun DL, Jiang X, Wu QL, Zhou NY. Intragenomic heterogeneity of $16 \mathrm{~S}$ rRNA genes causes overestimation of prokaryotic diversity. Appl Environ Microbiol. 2013;79(19):5962-9.

96. Ellis BK, Stanford JA, Ward JV. Microbial assemblages and production in alluvial aquifers of the Flathead River, Montana. USA J N Am Benthol Soc. 1998;17(4):382-402.

97. Zarda B, Mattison G, Hess A, Hahn D, Höhener P, Zeyer J. Analysis of bacterial and protozoan communities in an aquifer contaminated with monoaromatic hydrocarbons. FEMS Microbiol Ecol. 1998;27(2):141-52.

98. Ekelund F, Rønn R, Christensen S. Distribution with depth of protozoa, bacteria and fungi in soil profiles from three Danish forest sites. Soil Biol Biochem. 2001;33(4-5):475-81.

99. Girones R, Ferrús MA, Alonso JL, Rodriguez-Manzano J, Calgua B, de Abreu Corrêa A, et al. Molecular detection of pathogens in water-the pros and cons of molecular techniques. Water Res. 2010;44(15):4325-39.

100. Butina TV, Belykh Ol, Potapov SA, Sorokovikova EG. Diversity of the major capsid genes (g23) of T4-like bacteriophages in the eutrophic Lake Kotokel in East Siberia. Russia Arch Microbiol. 2013;195(7):513-20.

101. Khan IU, Gannon V, Kent R, Koning W, Lapen DR, Miller J, et al. Development of a rapid quantitative PCR assay for direct detection and quantification of culturable and non-culturable Escherichia coli from agriculture watersheds. J Microbiol Methods. 2007;69(3):480-8.

102. Sinclair $J L$, Alexander $M$. Effect of protozoan predation on relative abundance of fast-growing and slow-growing bacteria. Can J Microbiol. 1989;35(5):578-82.
103. Sinclair JL, Kampbell DH, Cook ML, Wilson JT. Protozoa in subsurface sediments from sites contaminated with aviation gasoline or jet fuel. Appl Environ Microbiol. 1993;59(2):467-72.

104. Clasen JL, Brigden SM, Payet JP, Suttle CA. Evidence that viral abundance across oceans and lakes is driven by different biological factors. Freshw Biol. 2008:53(6):1090-100

105. Vetrovsky T, Baldrian P. The variability of the $16 \mathrm{~S}$ rRNA gene in bacterial genomes and its consequences for bacterial community analyses. PLoS ONE. 2013;8(2), e57923.

106. Poretsky R, Rodriguez RL, Luo C, Tsementzi D, Konstantinidis KT. Strengths and limitations of $16 \mathrm{~S}$ rRNA gene amplicon sequencing in revealing temporal microbial community dynamics. PLoS ONE. 2013;9(4), e93827.

107. Liu J, Yu Y, Cai Z, Bartlam M, Wang Y. Comparison of ITS and 18S rDNA for estimating fungal diversity using PCR-DGGE. World J Microbiol Biotechnol. 2015;31(9):1387-95.

108. Anderson IC, Campbell CD, Prosser JI. Potential bias of fungal $18 \mathrm{~S}$ rDNA and internal transcribed spacer polymerase chain reaction primers for estimating fungal biodiversity in soil. Environ Microbiol. 2003;5(1):36-47.

109. Bellemain E, Carlsen T, Brochmann C, Coissac E, Taberlet P, Kauserud H. ITS as an environmental DNA barcode for fungi: an in silico approach reveals potential PCR biases. BMC Microbiol. 2010;10:189.

110. Zhou J, Wu L, Deng Y, Zhi X, Jiang YH, Tu Q, et al. Reproducibility and quantitation of amplicon sequencing-based detection. ISME J. 2011;5(8):1303-13.

111. Bokulich NA, Mills DA. Improved selection of internal transcribed spacer-specific primers enables quantitative, ultra-high-throughput profiling of fungal communities. Appl Environ Microbiol. 2013;79(8):2519-26.

112. Ibarbalz FM, Pérez MV, Figuerola ELM, Erijman L. The bias associated with amplicon sequencing does not affect the quantitative assessment of bacterial community dynamics. PLoS ONE. 2014;9(6), e99722.

113. Lamendella R, Domingo JW, Oerther DB, Vogel JR, Stoeckel DM. Assessment of fecal pollution sources in a small northern-plains watershed using PCR and phylogenetic analyses of Bacteroidetes 16S rRNA gene. FEMS Microbiol Ecol. 2007:59(3):651-60.

114. Thomas F, Hehemann JH, Rebuffet E, Czjzek M, Michel G. Environmental and gut bacteroidetes: the food connection. Front Microbiol. 2011;2:93.

115. Khanna S, Tosh PK. A clinician's primer on the role of the microbiome in human health and disease. Mayo Clin Proc. 2014;89(1):107-14.

116. Henriques IS, Alves A, Tacão M, Almeida A, Cunha Â, Correia A. Seasonal and spatial variability of free-living bacterial community composition along an estuarine gradient (Ria de Aveiro, Portugal). Estuar Coast Shelf Sci. 2006;68(1-2):139-48

117. Shanks OC, Newton RJ, Kelty CA, Huse SM, Sogin ML, McLellan SL. Comparison of the microbial community structures of untreated wastewaters from different geographic locales. Appl Environ Microbiol. 2013;79(9):2906-13.

118. Mesbah NM, Abou-El-Ela SH, Wiegel J. Novel and unexpected prokaryotic diversity in water and sediments of the alkaline, hypersaline lakes of the Wadi An Natrun. Egypt Microb Ecol. 2007;54(4):598-617.

119. Ghai R, Rodriguez-Valera F, McMahon KD, Toyama D, Rinke R, de Oliveira TC S, Wagner Garcia J, Pellon De Miranda F, Henrique-Silva F. Metagenomics of the water column in the pristine upper course of the Amazon river. PLoS ONE. 2011;6(8):e23785.

120. Jenkins SN, Waite IS, Blackburn A, Husband R, Rushton SP, Manning DC, O'Donnell AG. Actinobacterial community dynamics in long term managed grasslands. Antonie Van Leeuwenhoek. 2009;95(4):319-34.

121. Klausen C, Nicolaisen MH, Strobel BW, Warnecke F, Nielsen JL, Jorgensen NOG. Abundance of actinobacteria and production of geosmin and 2-methylisoborneol in Danish streams and fish ponds. FEMS Microbiol Ecol. 2005;52(2):265-78.

122. Nielsen JL, Klausen C, Nielsen PH, Burford M, Jorgensen NOG. Detection of activity among uncultured Actinobacteria in a drinking water reservoir. FEMS Microbiol Ecol. 2006;55(3):432-8.

123. Sylvan JB, Toner BM, Edwards KJ. Life and death of deep-sea vents: bacterial diversity and ecosystem succession on inactive hydrothermal sulfides. mBio. 2012;3(1):e00279-11.

124. Zhang Y, Sievert SM. Pan-genome analyses identify lineage- and niche-specific markers of evolution and adaptation in Epsilonproteobacteria. Front Microbiol. 2014;5:110.

125. Jezberová J, Jezbera J, Brandt U, Lindstrom ES, Langenheder S, Hahn MW. Ubiquity of Polynucleobacter necessarius ssp. asymbioticus in lentic freshwater habitats of a heterogeneous $2000 \mathrm{~km}^{2}$ area. Environ Microbiol. 2010;12(3):658-69. 
126. Jezbera J, Jezberová J, Brandt U, Hahn MW. Ubiquity of Polynucleobacter necessarius subspecies asymbioticus results from ecological diversification. Environ Microbiol. 2011;13(4):922-31.

127. Roux S, Enault F, Robin A, Ravet V, Personnic S, Theil S, et al. Assessing the diversity and specificity of two freshwater viral communities through metagenomics. PLoS ONE. 2012;7(3), e33641.

128. Rosario K, Duffy S, Breitbart M. Diverse circovirus-like genome architectures revealed by environmental metagenomics. J Gen Virol. 2009;90(10):2418-24

129. Jain A, Mittal N, Sharma PC. Genome wide survey of microsatellites in ssDNA viruses infecting vertebrates. Gene. 2014;552(2):209-18.

130. Weynberg KD, Wood-Charlson EM, Suttle CA, van Oppen MJ. Generating viral metagenomes from the coral holobiont. Front Microbiol. 2014;5:206.

131. Okafor N. Environmental microbiology of aquatic and waste systems. Chapter 4. New York: Springer; 2011. p. 84-7.

132. Lang AS, Culley Al, Suttle CA. Genome sequence and characterization of a virus (HaRNAV) related to picorna-like viruses that infects the marine toxic bloom-forming alga Heterosigma akashiwo. Virology. 2004;320(2):206-17.

133. Djikeng A, Halpin R, Kuzmickas R, DePasse J, Feldblyum J, Sengamalay N, Afonso C, Zhang XS, Anderson NG, Ghedin E, Spiro DJ. Viral genome sequencing by random priming methods. BMC Genomics. 2008;9:5.

134. Rosario K, Breitbart M. Exploring the viral world through metagenomics. Curr Opin Virol. 2011;1(4):289-97.

135. Kempsell KE, Cox CJ, Hurle M, Wong A, Wilkie S, Zanders ED, et al. Reverse transcriptase-PCR analysis of bacterial rRNA for detection and characterization of bacterial species in arthritis synovial tissue. Infect Immun. 2000;68(10):6012-26

136. Griffin DW, Stokes R, Rose JB, Paul JH. Bacterial indicator occurrence and the use of an F+ specific RNA coliphage assay to identify fecal sources in Homosassa Springs, Florida. Microb Ecol. 2000;39(1):56-64.

137. Cole D, Long SC, Sobsey MD. Evaluation of F+ RNA and DNA coliphages as source-specific indicators of fecal contamination in surface waters. Appl Environ Microbiol. 2003;69(11):6507-14.

138. Kircher M, Heyn P, Kelso J. Addressing challenges in the production and analysis of illumina sequencing data. BMC Genomics. 2011;12:382.

139. Michel A, Clermont O, Denamur E, Tenaillon O. Bacteriophage PhiX174's ecological niche and the flexibility of its Escherichia coli lipopolysaccharide receptor. Appl Environ Microbiol. 2010;76(21):7310-3.

140. Brown CJ, Millstein J, Williams CJ, Wichman HA. Selection affects genes involved in replication during long-term evolution in experimental populations of the bacteriophage phiX174. PLoS ONE. 2013;8(3), e60401.

141. Gual A, Camacho AG, Alonso JC. Functional analysis of the terminase large subunit, G2P, of Bacillus subtilis bacteriophage SPP1. J Biol Chem. 2000;275(45):35311-9.

142. Rao VB, Feiss M. The bacteriophage DNA packaging motor. Annu Rev Genet. 2008:42:647-81.

143. Telesnitsky A, Goff SP. Reverse transcriptase and the generation of retroviral DNA. In: Coffin JM, Hughes SH, Varmus HE, editors. Retroviruses. New York: Cold Spring Harbor; 1997.

144. Bowden TA, Jones EY, Stuart DI. Cells under siege: viral glycoprotein interactions at the cell surface. J Struct Biol. 2011:175(2):120-6.

\section{Submit your next manuscript to BioMed Central and we will help you at every step:}

- We accept pre-submission inquiries

- Our selector tool helps you to find the most relevant journal

- We provide round the clock customer support

- Convenient online submission

- Thorough peer review

- Inclusion in PubMed and all major indexing services

- Maximum visibility for your research

Submit your manuscript at www.biomedcentral.com/submit

) Biomed Central 